Studia Judaica 24 (2021), nr 2 (48), s. 491-533

doi:10.4467/24500100STJ.21.020.15075

Magdalena Ruta (iD https://orcid.org/0000-0003-0556-1694

\title{
Portrety podwójne, 1939-1956. Wspomnienia polskich Żydówek z sowieckiej Rosji
}

\author{
DOUBLE PORTRAITS, 1939-1956: \\ MEMOIRS OF POLISH JEWISH WOMEN FROM SOVIET RUSSIA
}

\begin{abstract}
During the first months following Germany's attack on Poland, some members of the Jewish community managed to sneak away to the eastern frontiers of the country which had been invaded and annexed by the Red Army in the second half of September 1939. The tragic experiences of these refugees, heretofore somehow neglected by Holocaust scholars, have recently become the subject of profound academic reflection. One of the sources of knowledge about the fate of Jewish refugees from Poland are their memoirs. In this article the author reflects on three autobiographical texts written by Polish Jewish women, female refugees who survived the Holocaust thanks to their stay in Soviet Russia, namely Ola Watowa, Ruth Turkow Kaminska, and Sheyne-Miriam Broderzon. Each of them experienced not only the atrocities of war, but also, most of all, the cruelty of the Communist regime. All three of them suffered persecution by the oppressive Soviet authorities in different ways and at different times. While Ola Watowa experienced (in person, as well as through the fate of her family and friends) the bitter taste of persecution and deportation during WWII, Sheyne-Miriam Broderzon lived a relatively peaceful life in that period (1939-1945), and Ruth Turkow Kaminska even enjoyed the luxurious lifestyle reserved for the privileged members of the establishment, and it was not until the years immediately after the war that the latter two women would face the true image of Communism as its victims. The Wats managed to leave the USSR shortly after the war, whereas for the Broderzons and the Turkows the war would not end until the death of Stalin and their subsequent return to Poland in 1956. According to Mary G. Mason, the immanent feature of women's autobiographical writings is the self-discovery of one's own identity through the simultaneous identification of some 'other.' It is thanks to the rootedness of one's own identity through the connection with a cer-
\end{abstract}


tain chosen 'other' that women authors can openly write about themselves. The aim of the article is to attempt to determine to what extent this statement remains true for the memoirs of the three Polish Jewish women who, besides sharing the aforementioned historical circumstances, are also linked by the fact that all of them stayed in romantic relationships with outstanding men (i.e. writers Aleksander Wat and Moyshe Broderzon, and jazzman Adi Rosner), which had an enormous impact not only on their lives in general, but also specifically on the creation and style of their autobiographical narratives, giving them the character of a sui generis double portrait.

Keywords: labor camp literature, memories, labor camps, exile, USSR, Stalinism, Ola Watowa, Ruth Turkow Kaminska, Sheyne-Miriam Broderzon, Aleksander Wat, Adi Rosner, Erika Rosner, Moyshe Broderzon, antisemitism, Holocaust, Polish-Jewish relations.

Słowa kluczowe: literatura łagrowa, wspomnienia, łagry, zesłanie, ZSRR, stalinizm, Ola Watowa, Ruth Turkow-Kamińska, Szejna-Miriam Broderzon Aleksander Wat, Adi Rosner, Erika Rosner, Mojsze Broderzon, antysemityzm, Zagłada, relacje polsko-żydowskie.

W pierwszych miesiącach po agresji niemieckiej na Polskę część społeczności żydowskiej, uciekając przed brunatnym terrorem, przedarła się na wschodnie rubieże państwa polskiego, zajęte w drugiej połowie września 1939 r. przez Armię Czerwoną. Zaniedbane przez badaczy Zagłady doświadczenia uciekinierów do ZSRR stają się w ostatnich latach przedmiotem pogłębionej refleksji. Jednym ze źródeł poznania ich losów są wspomnienia. Spośród badaczy polskiej literatury łagrowej - który to szeroki termin obejmuje nie tylko dzieła na temat pobytu w sowieckich obozach pracy przymusowej w okresie wojny i po jej zakończeniu, ale też na temat całego spektrum doświadczeń z okresu uchodźstwa i tułaczki po ZSRR zapoczątkowanych wybuchem II wojny, a zakończonych około roku 1955-1956 - jedynie Tadeusz Sucharski poddał głębszej refleksji literaturoznawczej większy korpus wspomnień, których autorami są Żydzi polscy¹. W ostatnim czasie ukazało się też kilka artykułów piszącej te słowa, gdzie przeanalizowane zostały wybrane wspomnienia z okresu sowieckiego - tym

1 Tadeusz Sucharski, Ocaleni w „domu niewoli”? Żydzi w polskiej literaturze doświadczenia sowieckiego, [w:] Syberiada Żydów polskich. Losy uchodźców z Zagłady, red. Lidia Zessin-Jurek, Katharina Friedla, Warszawa 2020, s. 241-304. 
razem spisane tylko w języku jidysz² . Należy jednak podkreślić, że są to badania skupione głównie na doświadczeniu mężczyzn. Tymczasem zarówno w literaturze polskiej, jak i w literaturze jidysz (a także w innych językach) nie brakuje relacji z łagrów i zesłania w głąb ZSRR autorstwa żydowskich kobiet, choć wspomnienia te są w zdecydowanej mniejszości. Stosunkowo rzadko w dotychczasowych badaniach tego gatunku uwzględniano perspektywę genderową, dlatego - jak to ujęła Tatiana Czerska warto tekstom wspomnień „zadać pytania, których im do tej pory nie stawiano"3.

\section{Doświadczenie kobiet}

Według Estelle Jelinek między autobiografią kobiecą a męską zachodzi kilka zasadniczych różnic. Zazwyczaj mężczyźni piszą przede wszystkim o dyskusjach publicznych, wydarzeniach historycznych, bieżącej polityce, sukcesach zawodowych czy rozwoju intelektualnym, natomiast kobiety skupiają się na doświadczeniach osobistych, domu, rodzinie, przyjaciołach czy ludziach ważnych w ich życiu. Mężczyźni przeważnie idealizują, mitologizują, a nawet monumentalizują swoje życie, kreśląc swój przesadzony portret jako człowieka pewnego siebie, a narracja ich wspomnień jest z reguły linearna i chronologiczna. Kobiety zaś, poszukując sposobu ekspresji dla swojego poczucia nieodpowiedniości i alienacji, posługują się elipsą, aluzją, dowcipem, a narracja ich autobiografii jest achronologiczna, fragmentaryczna, nielinearna, dygresyjna i epizodyczna oraz często operuje anegdotami, cytatami z listów i artykułów ${ }^{4}$. Powyższe spostrzeżenia Estelle Jelinek rozwija Mary G. Mason, zauważając, że w autobiografiach kobiecych nie można doszukać się wzorców ustanowionych

${ }^{2}$ Magdalena Ruta, "We were slaves": Deportation to a Soviet Forced Labor Camp during WWII as Depicted in the Memoirs of the Polish-Yiddish Writer Avrom Zak, ,Jewish Quarterly Review” 111 (2021), nr 1, s. 130-153; taż, Gułag poetów. Doświadczenie uchodźstwa, łagrów i tułaczki na terenie ZSRR w twórczości polskich pisarzy języka jidysz lat 1939-1949, [w:] Syberiada Żydów polskich..., s. 307-337; taż, Relacje polsko-żydowskie we wspomnieniach Awroma Zaka, jidyszowego twórcy „ocalatego na Wschodzie”. Rozpoznania wstęne, „Stosunki Polsko-Żydowskie. Kultura" 2 (2020), s. 103-129; taż, Plejtim 1939-1946. Doświadczenie sowieckiego uchodźstwa we wspomnieniach przedstawicieli polskiego Jidyszlandu. Prolegomena, [w:] Jidyszland. Nowe przestrzenie, red. Monika Adamczyk-Garbowska, Joanna Lisek, Magdalena Ruta [przyjęte do druku w 2022].

3 Tatiana Czerska, Kobiety w tagrach, „Annales Neophilologiarum” (2011), nr 5, s. 60.

${ }^{4}$ Estelle C. Jelinek, Introduction. Women's Autobiography and the Male Tradition, [w:] Women's Autobiography: Essays in Criticism, red. Estelle C. Jelinek, Bloomington 1980, s. $1-20$. 
przez dwóch prototypowych autobiografów męskich - św. Augustyna i Rousseau, skupionych na sobie i na swoim - zakończonym sukcesem rozwoju duchowym i intelektualnym. Według niej cechą konstytutywną dla autobiografiopisarstwa kobiecego jest odkrywanie własnej tożsamości poprzez akt jednoczesnej identyfikacji kogoś drugiego ${ }^{5}$ :

autoodkrycie kobiecej tożsamości potwierdza raczej rzeczywista obecność i rozpoznanie innej świadomości, a odkrycie kobiecego ,ja” wiąże się z identyfikacją kogoś „drugiego”. To rozpoznanie innej świadomości - podkreślam, rozpoznanie, a nie uległość - to zakotwiczenie tożsamości poprzez związek z wybranym innym, najwyraźniej [...] pozwala kobietom otwarcie pisać o sobie ${ }^{6}$.

Do takiej konstatacji badaczka dochodzi po analizie czterech tekstów autobiograficznych z różnych epok, z których każdy powstał dzięki relacji $\mathrm{z}$ „wybranym innym”. Przywołane przez nią przykłady odwołują się do związku z 1. drugą autonomiczną istotą, 2 . jednym transcendentnym innym (Bogiem), 3. dwoma innymi (Bogiem i mężem) czy 4. liczną zbiorowością, kilka w jednym ${ }^{7}$. Wyodrębnione modele odnajduje ona w licznych tekstach z różnych epok, dopowiadając zarazem, że „bez wątpienia istnieje wiele innych” rodzajów związków, jednak „liczba możliwych kombinacji na

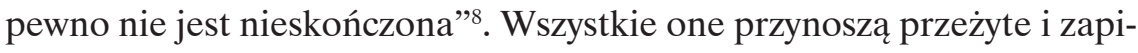
sane wzorce relacji z innymi, które pozwoliły kobietom „odkryć i wyznaczyć własne ja i opowiedzieć historię tego »ja « z okresu jego odkrywania i kształtowania".

W odniesieniu do kobiet funkcjonujących w cieniu sławnych mężczyzn krytyka feministyczna posługuje się, jak zauważa Inga Iwasiów, kategorią „niewidzialnych asystentek”10:

W historii jest ich wiele: ktoś miesza farby malarzom, ktoś ostrzy ołówki matematykom, jeszcze ktoś inny robi research w archiwum czy redaguje teksty. Dodajmy do tego stwarzanie warunków, krzątanie się wokół życia, a zrozumiemy, skąd w przeszłości było tylu wybitnych mężczyzn, a tak mało widocznych kobiet ${ }^{11}$.

5 Mary G. Mason, Inny głos: autobiografie pisarek, [w:] Autobiografia, red. Małgorzata Czermińska, Gdańsk 2009, s. 173.

6 Tamże.

7 Tamże, s. 201-202.

8 Tamże.

9 Tamże, s. 201.

${ }^{10}$ Inga Iwasiów, „Niosło ja to, że stała u boku”. O genderowym modelowaniu biografii artystek, „Autobiografia. Literatura. Kultura. Media” (2015), nr 2, s. 63-74.

${ }^{11}$ Tamże, s. 68. 
Badaczka dodaje, że na podstawowy model takich symbiotycznych relacji w parach artystycznych funkcjonujących w XIX i XX w. składają się następujące elementy: „skupienie na pisarzu, częsta rezygnacja z własnych ambicji, rozwijanie ich po śmierci współmałżonka i wreszcie rola kustoszki spuścizny”12. Czasami sytuacja takiej „niewidzialnej asystentki” zmienia się po śmierci męża, bo dopiero wtedy może ona przekroczyć przestrzeń domową. Dla artystek, pisarek czy innych wybitnych osobowości, które poniekąd zrezygnowały z siebie i poświęciły swoje życie wybitnym mężom, „[t]en gest przejścia, wyjście z cienia - prywatności, czynności służebnych jest decydujący"13.

Ponieważ tematem niniejszego artykułu jest analiza zapisu autobiograficznego kobiet, które w latach 1939-1956 krócej lub dłużej przebywały jako uchodźczynie w ZSRR, dlatego też warto przyjrzeć się opisanym sposobom reprezentacji doświadczenia kobiecego w tekstach o szeroko rozumianej wojnie i sytuacjach okołowojennych - jak pobyt w łagrze czy na połagiernej zsyłce określa Inga Iwasiów ${ }^{14}$. W jednym ze swoich artykułów zauważa ona, że zarówno w kanonie polskiej literatury wojennej, jak i na liście polskiej literatury łagrowej dominują mężczyźni ${ }^{15}$. Badaczka pyta, jakie trudności napotykają autorki tekstów autobiograficznych, kiedy - dając bezpośrednie świadectwo własnego doświadczenia „bycia ofiarą i bohaterką nieheroicznej codzienności” ${ }^{16}$ wojennej - muszą się zmagać z naporem dominującej, patriarchalnej tradycji pisania o wojnie, która wyznacza kobietom stereotypową rolę biernej „matki narodu, płaczki, zdolnej do poświęceń i doznającej wszelkiego zła" ${ }^{17}$, a doświadczenie męskie traktuje jako uniwersalne. Sięga przy tym do wybranych tekstów „pretendujących do miana autentyku"18 (wspomnień i powieści autobiograficznej), które poruszają wątki związane z seksualnością kobiecego podmiotu, czyli z tą najbardziej stabuizowaną w patriarchalnej narracji sferą życia kobiet. Ich analiza pozwala zaobserwować, w jaki sposób „zmiany konwencji przesuwają jednocześnie granice tego, co może zostać powiedziane” ${ }^{19}$ (od

12 Tamże.

13 Tamże, s. 69.

${ }^{14}$ Określenia takiego użyła Inga Iwasiów - zob. Inga Iwasiów, Centralna płeć cywila, [w:] Wojna. Doświadczenie i zapis: nowe źródta, problemy, metody badawcze, red. Sławomir Buryła, Paweł Rodak, Kraków 2006, s. 399-417.

${ }_{15}$ Tamże, s. 404-405.

16 Tamże.

17 Tamże, s. 400.

18 Tamże, s. 408.

19 Tamże, s. 413. 
dyskrecji i niedopowiedzenia w zakładającej referencyjność autobiografii po większą swobodę wypowiedzi w powieści z założenia pozwalającej podmiotowi skryć się za fikcją). Aby opowiedzieć o swoim doświadczeniu wykraczającym poza istniejące patriarchalne wzorce pisania - stwierdza Iwasiów - autorki wspomnień czy fikcji o charakterze autobiograficznym muszą uciekać $\mathrm{w}$ aluzję i niedopowiedzenie ${ }^{20}$. W konkluzji badaczka dodaje, że „wojenne” relacje kobiet charakteryzują się nie tylko (mniejszym lub większym) przemilczeniem i selektywną pamięcią, ale też obecnością małych narracji inicjowanych w sytuacji rozmowy czy zwierzenia, z których wyłaniają się migawkowe portrety innych kobiet - a wszystko to w celu utrwalenia i ocalenia pamięci o nich ${ }^{21}$.

Nieco inne pytanie zadaje tekstom łagrowym Tatiana Czerska, zastanawiając się, jak doświadczenia łagrowe zmieniły sposób postrzegania ludzkiej cielesności i fizjologii ${ }^{22}$. Zauważa przy tym, że relacje kobiet w porównaniu z męskimi mają charakter werystyczny i koncentrują się na fizycznych aspektach egzystencji, nie szukając uniwersalnych paraboli ${ }^{23}$. Kobiety są szczególnie wrażliwe na kwestie związane z ciałem i ludzką fizjologią, gdyż to im wpajane są surowe normy obyczajowe nakazujące dyskrecję wobec własnej cielesności, podczas gdy mężczyzn traktuje się bardziej liberalnie ${ }^{24}$. Stąd też ważne miejsce w kobiecych relacjach zajmują z jednej strony opisy upokarzających doświadczeń z seksualnością i fizjologią ciała pozbawionego intymności, będącego miejscem przymusowego doświadczania innych w zatłoczonej, śmierdzącej ludzkimi wyziewami przestrzeni ${ }^{25}$, a z drugiej wskazanie na próby ratowania własnej godności poprzez dbanie o higienę i zachowanie zewnętrznych wyznaczników płci (np. w ubiorze $)^{26}$ czy posłużenie się ciałem do zamanifestowania suwerenności wobec ideologicznych zakazów poprzez wykorzystanie własnej seksualności do stworzenia namiastki bliskości z drugą osobą ${ }^{27}$. Ważną kwestią, na którą również zwraca uwagę Czerska, jest destrukcja więzi międzyludzkich, zwłaszcza spajających rodzinę, do jakiej posuwał się system totalitarny sowieckiej Rosji ${ }^{28}$.

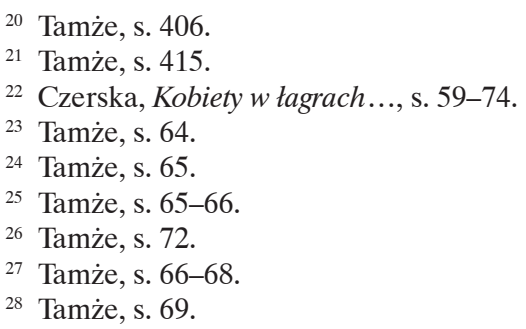


Autorem jednego z najnowszych opracowań poświęconych kwestii kobiecej w literaturze łagrowej autorstwa polskich pisarek jest wspomniany już wcześniej Tadeusz Sucharski, najważniejszy w ostatnich latach literaturoznawca systematycznie poddający ten gatunek literatury dokumentu osobistego wnikliwej refleksji naukowej ${ }^{29}$. Ustaliwszy, że termin „literatura łagrowa" nie ogranicza się do lat wojny (1939-1945), lecz rozciąga się aż po rok 1955-1956, kiedy to na fali odwilży ostatni polscy więźniowie zostali zwolnieni z sowieckich łagrów i uzyskali pozwolenie na repatriację, a także iż termin ten obejmuje nie tylko sam pobyt w obozach pracy przymusowej, ale również okres połagiernej zsyłki w głębi ZSRR, badacz ten zauważa, że nie ma jednego wzorca obozowego losu kobiet, który powtarzałby się w każdej kobiecej relacji. Ten jest bowiem zależny od wielu różnych czynników, wśród których wymienia takie jak: okres pobytu w łagrze (w czasie wojny lub po niej), długość przebywania (w jednym obozie lub w wielu), położenie geograficzne obozu czy wreszcie wiek łagierniczek (jak się bowiem okazuje, tylko najmłodsza pisze o fizjologii ciała czy o miłości fizycznej). Wiele z wyżej wymienionych szczegółów mogło zadecydować o przeżyciu, dlatego też:

Świadomości ich znaczenia uniemożliwia wręcz wypracowanie jakiejś jednej formuły, zamykającej łagrowe doświadczenie kobiet, zmusza do wstrzemięźliwości w artykułowaniu wniosków, do uwzględnienia wszystkich determinant losu obozowego: historycznego, czasowego, politycznego, geograficznego, organizacyjnego. W każdym jednak przypadku zawsze bardzo trudnego i nieludzkiego ${ }^{30}$.

Co ważne, wpływ na kształt relacji ma także czas spisywania wspomnień, czego dowodzi Sucharski, wskazując różnice między emocjonalnymi enuncjacjami zapisanymi tuż po uwolnieniu a zdystansowanymi, pełnymi refleksji zapiskami czynionymi po latach. Zwraca też uwagę na fakt, że polską wizję kobiety w łagrze sowieckim w największym stopniu ukształtował Gustaw Herling-Grudziński, autor kanonicznego Innego świata. Badacz nie chce jednak zaakceptować sytuacji, w której łagrowe życie kobiety zostaje ograniczone tylko do roli obiektu seksualnego ${ }^{31}$. Tym bardziej że:

Dzieła byłych łagiernic, nie kwestionując bynajmniej znaczenia kontaktów seksualnych, nie ograniczają się jedynie do tej sfery życia. Unaoczniają niezwykle trudną obozową egzystencję kobiet, obejmującą ich pracę ponad możliwości fizyczne, ży-

${ }^{29}$ Tadeusz Sucharski, Kobieta $w$ tagrze stalinowskim $w$ tekstach polskich pisarek, „Konteksty Kultury” 15 (2018), z. 1, s. 116-133.

${ }^{30}$ Tamże, s. 125.

31 Tamże. 
cie w łagrze ze wszystkimi jego przejawami [...], walkę o przetrwanie, o zachowanie godności ${ }^{32}$.

Przyjmując za punkt wyjścia powyższe ustalenia na temat specyfiki autobiograficznego pisarstwa kobiet oraz charakteru kobiecego doświadczenia w czasie wojny ${ }^{33}$ albo raczej - co dla mnie istotniejsze - w „sytuacji okołowojennej” (by ponownie zacytować Iwasiów), chciałabym swoją refleksją objąć trzy teksty autobiograficzne, których autorkami są polskie Żydówki - Ola Watowa, Ruth Turkow-Kamińska oraz Szejna-Miriam Broderzon. Reprezentują one trzy odmienne tożsamości żydowskie wyrażające się we wspomnieniach różnym stopniem zanurzenia w - lub oddalenia od - nowoczesnej, świeckiej jidyszkajt, pojmowanej tutaj nie tylko jako subiektywnie aprobowana przynależność etniczna, ale także jako uczestnictwo w społeczno-kulturalnym uniwersum języka jidysz. $\mathrm{Na}$ osi kontinuum pomiędzy modelem świeckiej jidyszkajt a pełną asymilacją do kultury dominującej każda z nich znajduje się w innym miejscu.

Najbardziej zanurzona w nowoczesnej jidyszkajt jest Szejna-Miriam Broderzon, żona wybitnego poety jidyszowego, która po jego śmierci osiadła w Izraelu, autorka wspomnień wydanych w prestiżowym wydawnictwie żydowskim, spisanych w jidysz, a więc przeznaczonych wyłącznie dla czytelnika żydowskiego. W jej relacjach jednostkowe myślenie o przeżytych cierpieniach nakłada się na myślenie z perspektywy kolektywu od wieków doświadczanego traumą (wrażliwość na tzw. żydowski los).

Ruth Turkow-Kamińska jako przedstawicielka wybitnej rodziny aktorskiej działającej na niwie wschodnioeuropejskiego teatru jidyszowego zdaje się zajmować pozycję pośrednią między pełną identyfikacją ze świecką jidyszkajt a postawą aprobującą proces pewnej integracji z kulturą dominującą (kulturami dominującymi). Wspomnienia Ruth można czytać jako świadectwo dokonującego się przejścia od tożsamości „tradycyjnej” do bardziej uniwersalnej, zanurzonej w wielu kulturach i językach. Świadczą o tym z jednej strony liczne wzmianki o przedwojennej przynależności do kultury jidysz w Polsce, kontaktach z aktorami jidyszowymi w ZSRR podczas wojny, posługiwaniu się jidysz w rozmowach z sowieckimi Żydami,

32 Tamże, s. 127.

33 Nowoczesna wojna, której bezpośrednie doświadczenie dotyka cywilów nie mniej niż mężczyzn walczących na froncie, pojmowana jest przez Ingę Iwasiów jako „koniec porządku i otwarcie na doznanie nieodwracalnej fragmentaryzacji”, wymuszające na cywilach „nowe sposoby uczestnictwa w świecie, które otwiera trauma nowoczesnego pola bitwy, obejmującego każdą możliwą przestrzeń”. Zob. Iwasiów, Centralna płeć cywila..., s. 404. 
a z drugiej - brak odwoływania się do kolektywnej świadomości typowej dla tradycyjnych autobiografii spisanych w tym języku ${ }^{34}$, bardziej neutralny, nieobciążony emocjonalnie stosunek do własnej żydowskości (Ruth wspomina o niej niejako na marginesie) czy wreszcie publikacja spisanej po angielsku relacji wspomnieniowej w jednym $\mathrm{z}$ londyńskich wydawnictw i wybór Nowego Jorku (po krótkim pobycie w Izraelu) na miejsce zamieszkania po emigracji z Polski.

Na osi ilustrującej kontinuum żydowskich tożsamości Ola Watowa reprezentuje tę część polskiego żydostwa, która świadomie i dobrowolnie zintegrowała się kulturowo z polskością, przyjmując podwójną, polsko-żydowską tożsamość ${ }^{35}$. W jej wspomnieniach żydowskość nie jest ani eskamotowana, ani przesadnie eksponowana, natomiast nieustannie podkreślany jest mocny związek z polskością nie tylko poprzez wybór języka i kultury, ale też poprzez twórczą aktywność na jej polu i bliskie związki z polskim środowiskiem twórczym. W kontekście tego artykułu ukoronowaniem wyborów tożsamościowych Oli Watowej i jej męża - wybitnego polskiego poety - jest publikacja w języku polskim wspomnień zrodzonych z inspiracji i przy współpracy polskiego środowiska emigracyjnego w Paryżu, gdzie mieszkała po śmierci Aleksandra.

Te trzy kobiety połączył wspólny los - los uchodźczyń, które ocalały z Zagłady dzięki pobytowi w sowieckiej Rosji. Swoim zasięgiem czasowym ich wspomnienia obejmują lata 1939-1956, czyli okres zdefiniowany przez Tadeusza Sucharskiego jako obejmujący całość doświadczenia sowieckiego

${ }^{34}$ Jan Schwarz zgadza się w swojej pracy - zob. Jan Schwarz, Imagining Lives: Autobiographical Fiction of Yiddish Writers, Madison 2005, s. 13-14 - z tezą historyka Jankewa Szackiego - zob. Jankew Szacki, Jidisze memuarn literatur, „Cukunft” (kwiecień 1925), s. 483 - iż niemal wszyscy pisarze jidyszowi spisujący swoje wspomnienia co do zasady nie modelują ich wedle wzoru rousseau'ańskiej spowiedzi, skupiając się przede wszystkim na życiu wspólnoty i podporządkowując mu życie osobiste i własną jaźń. Przyczyną tego ma być fakt, iż siłą napędową żydowskiego piśmiennictwa autobiograficznego były katastrofy historyczne (Schwarz, Imagining Lives..., s. 12).

${ }^{35}$ Ograniczone ramy tego tekstu nie pozwalają na rozbudowane wywody dotyczące szeroko już dyskutowanej kwestii złożonej tożsamości wielu pisarzy polskich pochodzenia żydowskiego. Na ten temat zob. np. Eugenia Prokop-Janiec, Żyd-Polak-artysta. O budowaniu tożsamości po Zagładzie, „Teksty Drugie” (2001), nr 1, s. 120-134, czy Magdalena Ruta, Literatura miejscem negocjowania tożsamości? Obraz relacji polsko-żydowskich w pisarstwie Kalmana Segala na tle literatury jidysz, [w:] Żydowski Polak, polski Żyd. Problem tożsamości w literaturze polsko-żydowskiej, red. Alina Molisak, Zuzanna Kołodziejska, Warszawa 2011, s. 112-127. Temat złożonej tożsamości polsko-żydowskiej z punktu widzenia socjologii omawia Małgorzata Melchior - zob. Małgorzata Melchior, Społeczna tożsamość jednostki (w świetle wywiadów z Polakami pochodzenia żydowskiego urodzonymi w latach 1944-1955), Warszawa 1990. 
(a więc nie tylko pobyt w łagrach, ale też połagierną tułaczkę po ZSRR) obywateli i obywatelek II Rzeczypospolitej Polskiej ${ }^{36}$. Jak słusznie zauważa ten badacz, łagier jest tutaj hasłem wywoławczym, metonimią continuum sowieckiej niewoli, cierpienia polskiego (w naszym przypadku również żydowskiego) i indywidualnego ${ }^{37}$. Każda ze wspomnianych autorek została doświadczona nie tylko okrucieństwem wojny per se, ale przede wszystkim okrucieństwem komunistycznego reżimu i prześladowaniem ze strony opresyjnej sowieckiej władzy - choć w różnym czasie i w różny sposób. W czasie wojny Ola Watowa osobiście i poprzez los najbliższych poznała smak prześladowań i zsyłki, dwie pozostałe zaś przeżyły lata 1939-1945 we względnym spokoju (Broderzonowie) czy nawet w luksusie przysługującym członkom establishmentu (Turkow-Kamińska i jej mąż), by dopiero w latach tużpowojennych odkryć prawdziwe oblicze komunizmu jako jego ofiary. Ola Watowa wraz z rodziną zdołała opuścić ZSRR zaraz po wojnie - w roku 1946, dla Ruth Turkow-Kamińskiej i Szejny-Miriam Broderzon wojna zakończyła się dopiero po śmierci Stalina, kiedy na fali odwilży roku 1956, po wielu latach starań, mogły wrócić do Polski wraz ze swoimi bliskimi. Ich wspomnienia - podobnie jak wspomnienia wielu innych - pozwalają „unaocznić łagrowość par excellence państwa stalinowskiego, ukazać Związek Sowiecki jako przestrzeń »wielkiej zony« z rozsypanymi po niej niezliczonymi »małymi zonami obozów «"38.

Czytając teksty przywołanych relacji, zwrócę uwagę na tematykę typową dla autobiografiopisarstwa kobiecego, ich styl, sposób prezentacji kwestii związanych z cielesnością i seksualnością, a także z innymi aspektami kobiecego losu w sowieckiej niewoli. Największy jednak wpływ na kształt niniejszych rozważań będzie miała teza Mary G. Mason, która - przypomnijmy - dowodzi, że kobiety-autorki - w odróżnieniu od mężczyzn mogą otwarcie pisać o sobie dzięki zakotwiczeniu własnej tożsamości poprzez związek z „wybranym innym”. Traktując za jej sugestią autobiografię kobiecą jako sui generis „,podwójny portret”, chciałabym sprawdzić, na ile teza ta jest prawdziwa w odniesieniu do wspomnień trzech przywołanych tu kobiet, które - poza wymienionymi wyżej okolicznościami historycznymi - łączy także fakt, że relacja z „wybranym innym” miała w ich przypadku szczególny charakter. Chodzi bowiem o bliski związek każdej z nich z wybitną indywidualnością, skupiającą na sobie spojrzenia

\footnotetext{
${ }^{36}$ Sucharski, Kobieta w tagrze stalinowskim..., s. 119-120.

37 Tamże, s. 120.

38 Tamże.
} 
innych. W jaki sposób relacja ta wpłynęła nie tylko na ich życie, ale także na samo powstanie wspomnień i strategię prowadzenia autobiograficznej narracji? W tle tych rozważań będzie również pytanie, czy przywoływana przez Iwasiów kategoria „niewidzialnej asystentki” znajdzie zastosowanie w każdym z trzech analizowanych przypadków ${ }^{39}$.

\section{Uchodźczy los}

Historie opisywane w większości wspomnień z pobytu w ZSRR układają się w pewien typowy schemat wydarzeń, które stały się udziałem wielu tysięcy żydowskich uciekinierów na wschodnie rubieże RP po wybuchu wojny ${ }^{40}$. Początkiem tego łańcucha wydarzeń była na przykład ucieczka w naszym przypadku z Warszawy czy Łodzi - ze względu na zagrożenie represjami ze strony niemieckich okupantów. Na liście osób do rozstrzelania byli zarówno pisarze Aleksander Wat, mąż Oli, i Mojsze Broderzon, mąż Szejny-Miriam, jak i wybitna aktorka Ida Kamińska, matka Ruth. Uchodźcy docierali do takich polskich metropolii na wschodzie jak Białystok (Broderzonowie, Kamińscy) czy Lwów (Watowie, później również Ruth $\mathrm{z}$ rodziną). $\mathrm{Z}$ ich relacji wyłania się smutny obraz polskich miast kresowych zajętych przez Armię Czerwoną i sowieckich urzędników, porównywanych do barbarzyńców ${ }^{41}$ ze względu na obce Polakom obyczaje, zniszczone odzienie, pożądanie rzeczy, które chcieli zdobyć za wszelką cenę (np. zegarki lub ubrania), czy posuwanie się do grabieży. Umacnianiu władzy sowieckiej towarzyszył powszechny głód, a w środowisku Polaków

39 Iwasiów, „Niosto ją to, że stała u boku”...

${ }^{40}$ Więcej na temat żydowskich wspomnień doświadczenia sowieckiego w języku polskim i jidysz zob. Sucharski, Ocaleni w „domu niewoli”?... oraz Ruta, Plejtim 1939-1946...

41 W większości wspomnień Polaków zamieszkujących miasta kresowe II Rzeczypospolitej Polskiej pojawia się taki właśnie obraz inwazji Armii Czerwonej i przedstawicieli sowieckiej władzy. Nie wchodząc w głębszą dyskusję nad tym zagadnieniem, chciałabym zwrócić uwagę, że na obraz ten składa się wiele czynników takich jak: typowe dla wojny, brutalne zachowanie najeźdźców wobec podbitej ludności, doświadczenia Kresowian ze spotkania z żołnierzami niedofinansowanej Armii Czerwonej, dla których pobyt w Białymstoku czy Lwowie był pierwszym kontaktem z bogatszym światem Zachodu, czy stereotypowe postrzeganie obywateli sowieckich jako niewykształconych, prymitywnych i nieokrzesanych, wypływające z myślenia postkolonialnego przypisującego zachodniemu światu wyższość (rasową i kulturową) nad światem wschodnim. W przypadku Polaków zasadniczą rolę odgrywały także stereotypy narosłe na istniejącej od XVIII w. rusofobii, pielęgnowane w licznych publikacjach II RP. Więcej o uprzedzeniach Polaków wobec Rosji i Rosjan zob. Tadeusz Sucharski, Polskie poszukiwania „innej” Rosji. O nurcie rosyjskim w literaturze Drugiej Emigracji, tu: rozdz. 1 - Drogi i bezdroża do „innej” Rosji, Gdańsk 2008. 
i Żydów polskich narodził się strach ze względu na panujące donosicielstwo i prowokacje, które kończyły się aresztowaniami, jak w przypadku Aleksandra Wata. Bliscy aresztowanych (tu: Ola Watowa, Ruth Turkow, nieco później również Szejna-Miriam) żywili złudne przekonanie o możliwości działania w ramach prawa, szukając pomocy adwokatów i urzędników. Wspólna im jest refleksja na temat osamotnienia po opuszczeniu przez zastraszonych przyjaciół, a także na temat braku wsparcia ze strony oficjalnie funkcjonujących instytucji takich jak Związek Literatów (piszą o tym Ola i Szejna-Miriam). Dla przywoływanych tu wspomnień kobiecych wspólnym rysem jest też motyw solidarności kobiet - żon aresztowanych mężczyzn, które (jak Watowa czy Broderzonowa) były gotowe zrobić wszystko, by im pomóc.

W tych - i w wielu innych - wspomnieniach ukazany jest ten sam schemat działania NKWD, którego funkcjonariusze zarówno w czasie wojny, jak i już po jej zakończeniu przychodzili do polskich domów nocą i dawali zaskoczonym ludziom zbyt mało czasu, aby się przygotować do dalekiej podróży w nieznane - do więzienia lub na zsyłkę (jak w przypadku Oli Watowej, Mojszego Broderzona czy Adiego Rosnera, męża Ruth). Aresztowani wyruszali, nierzadko wraz z rodzinami (jak Ola, którą zesłano z dziewięcioletnim synem), w długą i trudną podróż zatłoczonymi wagonami, pozbawionymi elementarnych wygód i udogodnień. Gwałtownie wyrwani z codzienności, zostawali bez podstawowych rzeczy niezbędnych do życia - np. ubrań czy butów, lub takich, które mogliby zamienić na chleb (o czym wspomina Ola Wat). Na zsyłce czy w łagrze zesłańcy żydowscy z Polski cierpieli głód i byli zmuszani do wykonywania ciężkiej pracy ponad siły (jak Watowie czy Mojsze Broderzon). Nie dziwią więc wzmianki na temat drobnych wykroczeń i kradzieży popełnianych przez nich dla zaspokojenia głodu własnego lub najbliższych.

Warto w tym miejscu podkreślić to, na co zwrócił uwagę Tadeusz Sucharski - w interesującym nas przedziale lat 1939-1956, obejmującym i II wojnę światową, i okres powojenny, dokonywały się w ZSRR rozmaite zmiany nie tylko pod względem politycznym, lecz też gospodarczym i społecznym. Nie miejsce tu na szczegóły, ale warto przypomnieć choćby to, że po wojnie nie było już takiego głodu jak w latach 1941-1945, a po zsyłce do miejsc przymusowego zamieszkania na przełomie lat czterdziestych i pięćdziesiątych nie wszyscy byli przymuszani do pracy ponad ludzkie siły. Ba, zdarzało się nawet, że tacy „późni” zesłańcy wręcz znaleźć pracy nie mogli, czego przykładem są losy Ruth Turkow-Kamińskiej. 
Wszyscy ci, którzy trafili do aresztu czy więzienia - bez znaczenia, czy podczas wojny, czy już po niej - doświadczali wielu upokorzeń. Do szczególnie przykrych zaliczyć można rewizję osobistą (wspomina o tym Ruth) czy też brak intymności przy załatwianiu potrzeb fizjologicznych oraz konieczność rozbierania się do naga w obecności wielu osób przed pójściem do łaźni (o czym wspominają Ruth i Ola). W większości wypadków upokarzające było nie tylko zachowanie służb więziennych, lecz sam pobyt w brudnych i zawszonych celach, gdzie zwykle nowo przybyłym wyznaczano miejsce do spania na ziemi w pobliżu paraszy (relacjonują to Ola i Ruth). W celi więziennej - podobnie zresztą jak w środowisku łagiernym - wyróżniali się więźniowie kryminalni (również kobiety): bezwzględni, okrutni, groźni, faktycznie sprawujący władzę. Co zaskakujące, wielu z nich było spragnionych rozrywki nieco bardziej szlachetnej niż bójki czy kradzieże, stąd też liczne wzmianki we wspomnieniach o sympatii, jaką wśród urków i worów cieszyli się niektórzy pochodzący z Polski więźniowe czy więźniarki (najczęściej wywodzący się ze sfery inteligenckiej) potrafiący zająć ich wyobraźnię, streszczając klasykę literatury światowej czy libretta znanych oper (to przypadek Aleksandra Wata oraz Ruth Turkow).

Co typowe dla gatunku, autorki wymienionych tu wspomnień łączy również poczucie związku z Polską jako ojczyzną - chociaż relacje autobiograficzne różnią się w szczegółach z racji odmiennych doświadczeń z polskim antysemityzmem w ZSRR. Jednak co do zasady kontakt z oazą polskości, jaką w czasie wojny były polska Delegatura rządu londyńskiego w ZSRR oraz skupiska formującej się wówczas Armii Andersa (przypadek Oli Wat), czy też wyznaczająca kres tułaczki i sowieckiej niewoli możliwość wyjazdu do Polski - w roku 1946 (Watowie) czy w połowie lat pięćdziesiątych (Broderzonowie i Ruth z córką) - stanowiły źródło najbardziej pozytywnych emocji, jakie towarzyszą człowiekowi powracającemu do domu. Symptomatycznym rysem tego fragmentu wszystkich trzech (ale i wielu innych) wspomnień jest także doświadczenie przemożnego stresu podczas opuszczania Rosji - z obawy przed ponownym aresztowaniem. Warto przy tym podkreślić, że powszechnie negatywnemu stosunkowi do państwa radzieckiego oraz do tzw. ludzi sowieckich, funkcjonariuszy wychowanych na ideologii i propagandzie komunistycznej, w większości wspomnień doświadczenia sowieckiego niemal zawsze towarzyszy pozytywne nastawienie autorów, a nawet współczucie, do cierpliwego narodu rosyjskiego (pod którym to pojęciem rozumie się zwykłych, prostych ludzi, niezajmujących się polityką i niesłużących reżimowi), od lat niezwykle 
doświadczanego przez władze sowieckie. Tego rodzaju nastawienie jest obecne również w analizowanych tutaj tekstach. Wspólna jest im również wrażliwość na tragiczny los takich podbitych narodów jak Czeczeńcy, Kazachowie czy Gruzini, którym Sowieci odebrali wolność i których ograbili z dóbr materialnych, w brutalny sposób narzucając komunizm i poddając ich demoralizującej propagandzie.

Tym - oraz wielu innym wspomnieniom z czasów sowieckich - wspólny jest również podstawowy cel, dla którego autorzy podjęli swój wysiłek. Jest nim potrzeba zaświadczenia o przeżyciach wyniesionych z ZSRR, udokumentowania męczeństwa zarówno własnego, jak i najbliższych oraz wielu obcych ludzi napotkanych po drodze. Aby wzmocnić swój przekaz i podnieść jego rangę jako dokumentu, a także aby zaświadczyć o prawdziwości zawartego z czytelnikiem paktu biograficznego ${ }^{42}$, wielu autorów tworzy narrację wielopoziomową. W przypadku omawianych tu tekstów do głównej narracji dołączone są obfite cytaty z listów, które autorki wówczas wymieniały z bliskimi (wszystkie teksty), z pism urzędowych, jak również wiersze czy zdjęcia, i to nie tylko z opisywanej epoki (Watowie, Ruth Turkow).

\section{Wszystko, co najważniejsze ${ }^{43}$}

Ola (właśc. Paulina) Wat (1903-1991) była tłumaczką i redaktorką spuścizny literackiej swojego męża Aleksandra Wata (1900-1967), wybitnego polskiego poety futurysty, związanego w okresie międzywojennym z komunizmem. Jej wspomnienia Wszystko co najważniejsze to efekt obszernego wywiadu, jaki w roku 1981 przeprowadził z nią Jacek Trznadel. Zebrane na taśmach rozmowy ukazały się w postaci książkowej w roku 1984 nakładem wydawnictwa Puls. Jak podkreśla Ola Wat, zostały one pomyślane jako suplement do obszernego wywiadu pt. Mój wiek, który w 1965 r. z Aleksandrem Watem przeprowadził Czesław Miłosz. Pod koniec lat osiemdziesiątych współpraca Watowej i Jacka Trznadla zakończyła się, a 1990 r. w Czytelniku ukazała się nowa wersja wspomnień, z których wycięto pytania tego drugiego, zamieniając rozmowę w monolog. Opracowania nowej wersji wspomnień podjął się Jan Zieliński, jednak jego

${ }^{42}$ Zob. Philippe Lejeune, Pakt autobiograficzny, thum. Aleksander Wit Labuda, „Teksty" (1975), nr 5, s. 31-49.

${ }^{43}$ Korzystam z następującego wydania: Ola Watowa, Wszystko co najważniejsze..., Warszawa 2011. 
nazwisko nie widnieje na stronie redakcyjnej książki ${ }^{44}$. Niepodzielną autorką wspomnień stała się sama Ola ${ }^{45}$.

We wspomnieniach ${ }^{46}$ Ola Watowa opowiada historię związku z Aleksandrem od początku po ostatnie dramatyczne lata jego życia zakończonego samobójstwem. Najwięcej miejsca zajmuje w nich relacja z pobytu w Związku Radzieckim w latach 1939-1946, która też interesuje mnie najbardziej. Losy rodziny Wata w czasie pobytu w ZSRR ilustruje następujące kalendarium:

- październik 1939 - ucieczka rodziny Watów z Warszawy do Lwowa;

- styczeń 1940 - aresztowanie Aleksandra we Lwowie;

- styczeń 1940 - październik 1941 - pobyt Aleksandra w więzieniach (Lwów, Kijów, Łubianka, Saratowo);

- marzec 1940 - zesłanie Oli i syna Andrzeja (dziewięć lat) do Kazachstanu (Iwanówka k. Żarmy, potem Antonówka pod Czymkentem);

- koniec 1941 - zesłanie Aleksandra do Ałma Aty (Ałmaty);

- 1942 - przybycie żony i syna do Ałma Aty;

- 1946 - powrót rodziny do Polski.

Styl narracji wspomnień Oli Watowej jest typowy dla języka mówionego, ale i dla narracji kobiet - charakteryzuje się licznymi dygresjami, retardacjami, zaburzeniami chronologii, asocjacyjnością, lecz także dbałością o elegancję wypowiedzi. W warstwie tematycznej wspomnienia snute są z perspektywy doświadczeń kobiecych. Przynoszą potwierdzenie przeczucia, że w kobietach-matkach drzemią niezwykłe moce, które dochodzą do głosu w sytuacjach granicznych - również w Oli pobyt z synkiem w ekstremalnie trudnych warunkach ujawnił hart ducha. Jak sama stwierdza, potrafiła sprostać bardzo trudnym wyzwaniom dzięki świadomości, że życie i zdrowie jej dziecka zależą tylko od niej. Jej opowieść o tym aspekcie doświadczenia kobiecego to historia o zapobiegliwości matki i żony, która jest gotowa kraść i ryzykować życiem, by nakarmić dziecko, i która nie waha się szukać pomocy u enkawudzisty, żeby zapewnić rodzinie jak najbezpieczniejszą podróż powrotną do Polski. To również wzmianki

${ }^{44} \mathrm{~W}$ wydaniu z roku 2011 jego nazwisko jest tylko wzmiankowane w lakonicznym posłowiu od autorki, umieszczonym na końcu książki. Zob. tamże, s. 287.

${ }^{45}$ Historię tych przemian i ich zakulisowe szczegóły opowiada Anna Gawryś - zob. Anna Gawryś, Meandry współautorstwa. Przypadek Oli Watowej, [w:] Artyst(k)a: obecność i tożsamość. Manifestacje podmiotowości w gestach i procesach twórczych, red. Magdalena Popiel, Klaudia Węgrzyn, Maciej Kuster, Kraków 2018, s. 29-45.

${ }^{46}$ Idąc tropem woli Pauliny Watowej, odwołuję się do tej wersji wspomnień, których jest jedyną autorką. 
o zagrożeniu przemocą seksualną ze strony mężczyzn w sytuacji konfliktu czy napaści przez pijanych. A także istniejąca na marginesie głównej narracji opowieść o przemocy useksualizowanej ${ }^{47}$, jakiej doświadczyła w więzieniu, do którego trafiła za odmowę przyjęcia sowieckiego paszportu w marcu $1943 \mathrm{r}$.

Strategię pisarską Oli Wat, kiedy opowiada o tego typu doświadczeniach, można by nazwać strategią obserwatorki, bo często obserwatorka wygrywa w niej z uczestniczką. Nierzadko obraz, który chce przekazać czytelnikowi, jest mimo swojej drastyczności jakby naszkicowany miękką kreską. Wyraźnie wyczuwa się w jej opowieści tendencję do łagodzenia czy pomijania drastycznych szczegółów. Przykłady tego znajdziemy choćby w relacji z podróży eszelonem na miejsce zsyłki, podczas której rozpoznano w Oli żonę „komunisty” Wata, przez co popadła w ostracyzm całej wagonowej społeczności podejrzewana o donosicielstwo. Wyliczywszy zaledwie kilka sytuacji konfliktowych, w efekcie których wręcz mogło być zagrożone życie Andrzeja, jej synka, autorka wspomnień konkluduje:

Nie będę wdawać się we wszystkie szczegóły naszej trzytygodniowej jazdy w tym wagonie, wśród ludzi, którzy nas nienawidzili, widzieli we mnie niebezpiecznego wroga. I chociaż byłam na tym samym co oni dnie nędzy i poniewierki, nie znalazł się ani jeden człowiek, który by usiłował bodaj sprawdzić to, co usłyszał, pomówić ze mną na ten temat, przekonać się, że może się mylą, że jestem tak samo, jak i oni, więźniem ${ }^{48}$.

To, co zbyt osobiste, sugerowane jest w jej opowieści przez niedomówienie, przez odwołanie się do pozornie nieistotnego szczegółu, który jednak rzuca światło na to, co istotne. Niewątpliwie odległa perspektywa czasowa, z jakiej autorka przywoływała relacjonowane wydarzenia, miała wpływ na odtwarzanie szczegółów, ale też sytuacja wywiadu, który przeprowadzał z nią mężczyzna, mogła nie sprzyjać snuciu osobistych kobiecych zwierzeń. Dlatego zapewne, gdy opowiada o doświadczeniach zbyt intymnych, pomija własne odczucia, skupiając się na okolicznościach towarzyszących.

47 Posługuję się tym pojęciem za Agnieszką Nikliborc, która w ten sposób przełożyła określenie „sexualisierte Gewalt” ukute przez autorki książki: Helga Amesberger, Katrin Auer, Brigitte Halbmayr, Seksualisierte Gewalt: Weibliche Erfahrungen in NS-Konzentrationslagern, Wien 2004. W ślad za tymi badaczkami Nikliborc wyjaśnia, że przemoc useksualizowana obejmuje nie tylko przypadki bezpośredniej agresji fizycznej, ale też ograniczenie intymności, złe warunki higieniczne, ubrania niewystarczające dla poczucia komfortu. Więcej zob. Agnieszka Nikliborc, Uwięzione w KL Auschwitz-Birkenau. Traumatyczne doświadczenia kobiet odzwierciedlone w dokumentach osobistych, Kraków 2010, s. 170-171.

${ }^{48}$ Watowa, Wszystko co najważniejsze..., s. 61-62. 
Przykładem może być relacja na temat tego, co ją spotkało po aresztowaniu za odmowę przyjęcia sowieckiego paszportu:

Kiedyśmy przybyli na miejsce, jakiś ponury mężczyzna w ciemnym fartuchu kazał mnie i Regince rozebrać się do naga. Jak to. Tutaj? Na tym małym podwórku, z którego wchodziło się do łaźni i gdzie stało jeszcze kilku żołnierzy, przybyłych tu prawdopodobnie z jakimś transportem więźniów? Dozorujący mężczyzna popędzał nas, aby się szybko rozebrać. Już bez żadnego odruchu obrony zaczęliśmy składać na brzegu podwórza nasze ubrania. I kiedy byłam już prawie naga, jeden z żołnierzy nagle zdjął z siebie swój płaszcz i zrobił z niego parawan dla mnie. Powiedział: „Teraz nikt was nie widzi”. W głosie tym wyczułam litość i wstyd. Wstyd za funkcję, którą mu wyznaczono ${ }^{49}$.

Wątek towarzyszącej temu wydarzeniu traumy jest w narracji wyciszony. I tylko na podstawie pozornie mało znaczącego dopowiedzenia o tym, jak zareagował jeden z obecnych tam żołnierzy, czytelnik może się domyślić stopnia dyskomfortu doświadczanego wówczas przez narratorkę wspomnień.

Oprócz techniki przenoszenia uwagi na okoliczności towarzyszące autorka posługuje się też strategią łagodzenia kontrastów, zacierania ostrych barw czy nawet idealizowania pewnych sytuacji. Przykłady tego możemy znaleźć choćby w refleksjach na temat osób związanych z komunizmem, np. Stefanii Skwarczyńskiej, Wandy Wasilewskiej czy Władka Daszewskiego - człowieka uczestniczącego w prowokacji, na skutek której aresztowano przedstawicieli polskiej inteligencji we Lwowie (w tym samego Wata). Ola próbuje załagodzić ciągnącą się za nimi złą sławę, ukazując ich ludzkie oblicze - stąd rozbudowane opowieści na temat pomocy, jakiej Wasilewska udzielała Polakom w okresie lwowskim czy o pięknie duchowym Skwarczyńskiej, z którą autorka spędziła kilka miesięcy na zsyłce w Kazachstanie, a także próba zrozumienia motywów kierujących Daszewskim, gdy zdecydował się wystawić Wata enkawudzistom. Innym ciekawym przykładem jest opowieść o Walentym, kryminaliście poznanym przez Aleksandra w areszcie. Człowiek ten, uciekłszy z więzienia, odwiedził przebywającą na zesłaniu rodzinę Wata. Ta historia jest doskonałym przykładem tendencji Oli Watowej do rysowania sekwencji wydarzeń miękką kreską i czegoś, co nazwałabym romantyzacją. W opowieści o spotkaniu z groźnym Walentym - przyjacielem Aleksandra z więzienia - nie wyczuwa się żadnego napięcia, nie ma w niej poczucia zagrożenia czy strachu,

49 Tamże, s. 169. 
chociaż człowiek, który odwiedza rodzinę z dzieckiem, to groźny urka mający na sumieniu ludzkie życie:

Aleksander patrzył przez chwile na niego, a potem zerwawszy się z kojki, podbiegł i całując go w oba policzki, wolał: „To jest Walentyn, Walentyn!”. Podbiegłam wzruszona i z uczuciem ogromnej wdzięczności ściskałam jego rękę. Andrzej [syn Watów - MR] stał z boku i patrzył zafascynowany. Pierwszy raz w życiu widział prawdziwego bandytę, katorżnika ${ }^{50}$.

W ustach Oli Watowej relacja o nim to opowieść o łagodnym człowieku, który ma piękną duszę.

O (fizycznej i duchowej) obecności męża w życiu Oli świadczą przede wszystkim liczne stematyzowane uwagi o łączących ich relacjach, tęsknocie, potrzebie kontaktu czy wzmianki o bólu, jakiego doświadczała na myśl o jego trudnym losie. To też obszerne refleksje na temat świadomej decyzji o uzupełnieniu literackiej spuścizny zmarłego. To wreszcie stwierdzenie, że: „Wszystko, co najważniejsze w moim życiu, wiąże się z Aleksandrem”, z którego został wywiedziony tytuł jej wspomnień. A także liczne zdjęcia przywołujące jego postać oraz obficie cytowane wypowiedzi, a zwłaszcza listy, które nie tylko są znakiem łączących ich uczuć, ale przede wszystkim pozwalają przemówić jemu samemu. O żywym związku dusz świadczą też mniej lub bardziej świadomie umieszczane w opowieści sygnały, z których nietrudno odczytać, jak bardzo myśli Oli były skoncentrowane na osobie Aleksandra. Doskonałym przykładem jest opowieść o tym, jak odebrawszy $\mathrm{z}$ więzienia brudną bieliznę męża do prania, zorientowała się, że jego skarpetki są wypchane watoliną. Wyobraźnia od razu dostrzegła w tym znak zapowiadający rychły powrót Aleksandra do domu. Watolina w połączeniu ze skarpetkami ułożyła się w przesłanie: „Wat przyjdzie do Oliny”52.

Obecność Aleksandra, wybitnego poety i intelektualisty, widoczna jest także poprzez ślady, które odcisnął na sposobie myślenia i postrzegania świata swojej żony. Ślady te odnajdziemy na przykład w opowieści, jak doświadczanie urody kazachskiego stepu, na którym Ola mieszkała po zesłaniu, pomogło jej przetrwać trudy tamtych chwil:

Wszystko stało się tak niezmiernie znaczące i oddziaływało na nas w jakiś sposób dobroczynny. Uroda stepu, księżyc strugą poprzez ściany szałasu oświetlający śpiących, zmordowanych kilkunastogodzinną pracą ludzi. Ludzi głodnych. Ta uroda

50 Tamże, s. 190-195.

${ }^{51} \mathrm{Na}$ „techniczny” charakter tego stwierdzenia zwróciła uwagę Anna Gawryś, podkreślając, że nie jest to wyznanie. Zob. Gawryś, Meandry wspótautorstwa ..., s. 30.

${ }^{52}$ Watowa, Wszystko co najważniejsze..., s. 59. 
była dla mnie jakby znakiem Boga, który gdzieś wysoko i daleko czuwa nad nami. Ta uroda właśnie to jedyny jakby tutaj dowód istnienia Boga. Nie chcę wydać się patetyczna albo udawać teraz to, co nie pokrywa się z prawdą owych lat, ale ja naprawdę wiem, że moja wrażliwość i to, że w latach nieludzkich warunków potrafiłam przeżywać piękno - to może mnie w jakiś sposób ratowało i dodawało sił ${ }^{53}$.

Ta uwaga o roli i znaczeniu kontemplacji przyrody - a więc przeżyć z pogranicza metafizyki i religijnego zachwytu - może nasuwać skojarzenie z religijnym nawróceniem, którego doświadczył jej mąż w celi więzienia w Saratowie w roku 1941. Być może opowieści męża o jego przeżyciach duchowych odcisnęły piętno na jej wyobraźni i na sposobie, w jaki jej pamięć odtwarzała przeszłość z tamtego okresu. Śladów bliskości Aleksandra Wata-poety można doszukiwać się również we wrażliwości, z jaką Ola reaguje na piękno języka, poezję słów wypowiadanych przez prostych ludzi. I tak na przykład czyni zaskakujące wyznanie, opowiadając o konflikcie, jaki rozegrał się między nią a pewnym Kazachem sprawujaccym władzę w kołchozie, gdy zaniedbała swoje obowiązki pracownicy, walcząc o zdrowie dziecka:

Kazach, od którego zależałam, był postrachem nas wszystkich. Nazywano go stiepnoj wotk. Nie wiadomo, w jakich okolicznościach stracił jedną rękę. Na twarzy miał ślady po ospie. Dosiadał stepowych koni i pędził na nich jak szalony. Był mały i krępy, cały sklecony z muskułów, bardzo silny. „No cóż - powiedział - jak ci syn podochniet, zrobię ci innego". I zaraz w następnym zdaniu u tego dzikusa ta zadziwiająca poezja. Nagle przyciszył głos i już zupełnie innym, jakimś miękkim tonem dodał: „Tylko ziemia, niebo i gwiazdy będą tego świadkami”. Utkwiło mi w pamięci to zdanie w ustach człowieka, który wydawał mi się naczyniem najprymitywniejszych instynktów ${ }^{54}$.

Obecność „wybranego innego”, którym w jej przypadku jest Aleksander Wat, zostaje potwierdzona świadomą decyzją o uzupełnieniu spuścizny zmarłego męża poprzez dopisanie tych szczegółów z pobytu w Związku Radzieckim, o których nie zdążył opowiedzieć sam. Ta właśnie decyzja stała się zarazem początkiem jej walki o zaistnienie jako pisarka. Jako powód wykreślenia nazwiska Trznadla z kolejnych wydań wspomnień Ola Watowa podawała różnicę zdań, do jakiej doszło między nimi, ale konflikt prawdopodobnie miał głębsze podłoże. Posługująca się kluczem psychoanalitycznym badaczka Anna Gawryś, porównawszy magnetofonowy zapis rozmów z wersją drukowaną, doszła do wniosku, że Watowa

53 Tamże, s. 81.

${ }^{54}$ Tamże, s. 84. 
postąpiła w ten sposób, ponieważ chciała odzyskać kontrolę nad tekstem, przywrócić go sobie. Czemu jej na tym zależało? Wiemy z relacji osób z nią zaprzyjaźnionych, że była dobrą gawędziarką i zawsze marzyła o pisaniu, ale miała problem z przelewaniem myśli na papier. Jednak pragnienie pisania, stworzenia własnego tekstu, wypływało nie tylko z jej ambicji i marzeń, lecz miało też głębszą motywację. Było rodzajem zobowiązania wobec męża, a może nawet zrodziło się pod wpływem presji, jaką wywierał na nią nawet po śmierci. Aleksander Wat, znając jej talent narracyjny, zostawił dokładne instrukcje, w jaki sposób powinna wykorzystać jego notatki gromadzone z myślą o kontynuowaniu dzieła poświęconego tułaczce wojennej po Związku Radzieckim. Żona miała dokończyć to, czego on nie zdążył zrobić. Wat dosłownie zaprojektował jej książkę. Anna Gawryś podsumowuje:

Współautorstwo było jej potrzebne, by uwolnić mowę, ale też - jak się okazało - by wreszcie zostać autorką „własnej” książki, czyli by ostatecznie oddzielić pismo od mowy. Owa szczególna droga na wspak: od współautorstwa, i to nawet współautorstwa podwójnego (Trznadel, Zieliński), do autorstwa wywalczonego drogą nie najuczciwszą, stanowi jakby walkę o własne, czyli niezapośredniczone słowo pisane i o własne dzieło ${ }^{55}$.

Przypadek Oli Watowej jest szczególny - działania podjęte przez nią wiele lat po śmierci męża świadczą o tym, że ostatecznie nie zadowoliła się funkcją strażniczki jego spuścizny i zapragnęła wyjść z roli „niewidzialnej asystentki”, by zaistnieć w przestrzeni publicznej jako autorka własnego dzieła - nawet za cenę swoistego oszustwa.

\section{Futro z norek i druty kolczaste}

Wspomnienia Mink Coats and Barbed Wire Ruth Turkow-Kamińskiej (1919-2005), córki znanej aktorki Idy Kamińskiej (1899-1980), żony wybitnego trębacza jazzowego Adiego Rosnera (1910-1976), ukazały się w Londynie w roku 1979, tj. dwadzieścia trzy lata po wyjeździe autorki z córką ze Związku Radzieckiego, dziesięć lat po emigracji z Polski do Stanów Zjednoczonych, trzy lata po śmierci męża ${ }^{56}$. Nie pojawia się w nich informacja, kiedy Ruth zaczęła pisać (ukończyła je nie później niż

${ }^{55}$ Gawryś, Meandry wspótautorstwa..., s. 43.

${ }^{56}$ Ruth Turkow Kaminska, Mink Coats and Barbed Wire, wstęp Harrison E. Salisbury, London 1979. 
w 1978 r., o czym świadczy data przyznania jej copyright), czy też jaki był bezpośredni impuls, który ją do tego popchnął. Symptomatyczny jest fakt, że nie ukazały się w Polsce, gdzie mieszkała przez ponad dziesięć lat po opuszczeniu Związku Radzieckiego. Najprawdopodobniej w tamtym czasie było to niemożliwe ze względów politycznych. Tymczasem na Zachodzie, zwłaszcza w Stanach Zjednoczonych, już od lat czterdziestych prowadzono ożywione dyskusje na temat zbrodni systemu komunistycznego w Związku Radzieckim, Ruth nie musiała się więc obawiać, że jej głos zostanie stłumiony lub będzie przyczyną krytycznych dyskusji. Warto podkreślić, że wspomnienia te zostały wydane w języku angielskim, a zatem już wybór języka jest sygnałem, dla jakiego czytelnika były przeznaczone - nie dla Polaków czy Rosjan, lecz dla mieszkańców świata zachodniego. Świadczą o tym również przypisy dotyczące najnowszej historii państw Europy Środkowo-Wschodniej. Z pewnością dzieło to nie było też pomyślane wyłącznie dla odbiorców żydowskich, czego dowodzi nie tylko język, ale też pewna uniwersalizacja opowieści i przeniesienie akcentu z doświadczeń żydowskich na ogólnoludzkie.

Cel wspomnień nie został explicite sformułowany, ale ze wstępu autorstwa znanego amerykańskiego dziennikarza-sowietologa Harrisona E. Salisbury'ego ${ }^{57}$, a także z gęsto rozsianych po całej książce opowieści o tragicznych losach napotykanych przez autorkę ludzi (głównie kobiet), również skrzywdzonych przez stalinizm, możemy wnioskować, że chciała ona nie tylko udokumentować tragiczną epokę w swoim życiu, ale też zaświadczyć o cierpieniach rodziny i tych wszystkich, których historie poznała. Aby podkreślić prawdziwość swojej relacji, tworzy - podobnie jak Ola Wat - narrację wielopoziomową, wprowadzając do opowieści podstawowej głosy zapisane w listach, a także liczne fotografie. Poza tym możemy się domyślać, że - jak w wielu innych wypadkach - spisanie wspomnień o przeżytej traumie mogło mieć również działanie terapeutyczne. Niewykluczone, że pisząc, Ruth miała na myśli też dialog z własną córką, której należały się wyjaśnienia, dlaczego ojca i matki nie było przy niej przez pięć czy sześć lat trudnego dzieciństwa. A może po prostu pisała dla wnuków? Nie można też wykluczyć, że bezpośrednim impulsem do przelania myśli na papier była śmierć byłego męża w 1976 r. Prawdziwych powodów możemy się tylko domyślać.

57 Zob. krótką biografię Salisbury'ego: https://www.britannica.com/biography/Harrison-E-Salisbury [dostęp: 11 lipca 2021]. 
Wspomnienia składają się z 31 rozdziałów, których treść ułożona jest chronologicznie, oraz postscriptum (Postscript), w którym opowiada, jak potoczyły się losy niektórych osób wspomnianych wcześniej. Wszystkie części mają przemyślaną budowę, a każdy rozdział obejmuje zamkniętą historię składającą się z jednego lub kilku epizodów. Zazwyczaj kończą się one puentą, która jest podsumowaniem opowiedzianej historii lub zapowiada przyszłe wydarzenia. Fabuła obejmuje 15 lat i rozpada się na dwie części: lata 1939-1946 (10 rozdziałów) i 1946-1956 (21 rozdziałów). Chronologię opisanych w nich wydarzeń obrazuje następujące kalendarium:

- jesień 1939 - ucieczka rodziny (Ruth i Adiego oraz jej matki Idy z mężem Meirem Melmanem) do Białegostoku, potem do Lwowa;

- 1939-1946 - przychylność Stalina umożliwiająca rozwój kariery artystycznej Adiemu, którego jazz-band koncertuje na terenie całego ZSRR (Ruth występuje z nim jako piosenkarka);

- 1941 - narodziny córki Eriki;

- listopad 1946 - aresztowanie Adiego;

- grudzień 1946 - aresztowanie Ruth;

- 1946-1954 - wielomiesięczny pobyt Adiego w więzieniu i realizacja wyroku skazującego na dziesięcioletni pobyt w łagrze (Chabarowsk, Kołyma);

- 1946-1951 - siedmiomiesięczny pobyt Ruth w więzieniu zakończony pięcioletnim zesłaniem do miasteczka Kokczetaw w Kazachstanie, przenosiny do Karagandy;

- 1951-1953 - zakończenie wyroku Ruth; zakaz powrotu do Moskwy, tułaczka w poszukiwaniu stabilizacji (domu i pracy): Mińsk, Homel, Tuła, Riazań;

- 1953 - powrót Ruth do Moskwy;

- 1955 - powrót Adiego do Moskwy, rozpad małżeństwa;

- 1956 - wyjazd Ruth z córką Eriką do Polski.

Pierwsza faza - faza względnie stabilnego, a nawet początkowo luksusowego życia, kiedy to za zgodą samego Stalina jazz-band Rosnera koncertował w całym ZSRR dla sowieckiej wierchuszki - kończy się wówczas, kiedy Ruth i Adi podejmują decyzję o powrocie do Polski jesienią 1946 r. (wcześniej do Polski wróciła jej matka Ida z mężem i synkiem Wiktorem). Lata tużpowojenne to w ZSRR okres narastania zimnowojennej retoryki i nastrojów antysemickich. Adi Rosner zostaje wówczas aresztowany jako propagator „wrogiej” muzyki jazzowej i szpieg obcego wywiadu. Dwa 
tygodnie po nim do więzienia trafia również Ruth. Tak więc wydarzenia z końca roku 1946 roku stanowią zarazem początek drugiej fazy życia w ZSRR, na którą przypada pobyt w więzieniach oraz na zesłaniu. Adi trafia do łagru, a Ruth po siedmiu miesiącach więzienia zostaje zesłana do Kokczetaw, małej miejscowości w Kazachstanie. Koniec tego okresu przypada na lata 1955-1956, kiedy to po zakończeniu wyroków oboje zostają zrehabilitowani. Adi decyduje się pozostać w Związku Radzieckim (Ruth nie podaje szczegółów dotyczących tej decyzji), a ona z córką po roku starań wyjeżdżają do Polski. Chwytliwy tytuł Futro z norek $i$ druty kolczaste doskonale oddaje tę podwójność wspomnieniowej opowieści. Jej narracja jest płynna, żywa, miejscami dowcipna, zawiera liczne dygresje, retardacje i dopowiedzenia snute na zasadzie asocjacji - nieco przypominając pod tym względem opowieść Oli Watowej. Przynosi głównie relacje z następujących po sobie wydarzeń czy opisy napotykanych osób, o wiele mniej miejsca niż Wszystko co najważniejsze poświęcając rozważaniom o charakterze refleksji bądź intymnej spowiedzi. Można więc rzec, iż w opowieści funkcja świadectwa dominuje nad funkcją wyznania ${ }^{58}$.

Poza warstwą fabularną, dość typową dla opowieści tego typu, wspomnienia Turkow-Kamińskiej są również zapisem jej indywidualnych doświadczeń jako kobiety. Najczęściej ten aspekt ujawnia się wówczas, kiedy mowa o doświadczaniu ciała. W przeciwieństwie do Oli Watowej autorka często podkreśla dyskomfort, jaki towarzyszył jej z powodu trudności w utrzymaniu higieny. Ciało domagało się umycia, brudne ubrania żądały, by je wyprać. Brud i poczucie nieświeżości drażniły bardziej niż brak ciepłych rajstop czy ciepłych butów zimą:

każdego ranka po liczeniu byłyśmy wypuszczane w grupach po trzydzieści. Jedna grupa wynosiła paraszę do latryny i opróżniała ją. [...] Gdy tylko docierałam na miejsce, rozbierałam się i podawałam ciuchy osobie za mną. Potem myłam się. Woda była zimna. Przez zakratowane okna bez szyb tuż pod sufitem wpływało powietrze z zewnątrz. Była zima.

Najpierw Marusia [jedna z kryminalnych - MR] śmiała się ze mnie. Ale gdy opowiedziałam Czerwonej Marusi [inna kryminalna więźniarka - MR] o wielkich damach i później wyjaśniłam, że czystość pomaga zapobiegać chorobom, Marusie również zaczęły się myć i zmuszały do tego inne. [...]

${ }^{58}$ Więcej na temat trzech dominujących postaw prezentowanych przez autorów we wspomnieniach zob. Małgorzata Czermińska, Autobiograficzny trójkąt. Swiadectwo, wyznanie $i$ wyzwanie, Kraków 2004, s. 11-52. 
Potem Marusie przymusiły dziewczyny w celi do czyszczenia desek, na których spałyśmy [...]. Niebawem kobiety zaczęły prać szmatki, których używały podczas menstruacji, susząc je w oknie tuż obok mnie.

Zapewne dlatego, że wszystkie były zamknięte tak długo razem, doświadczyły fizjologicznej synchronizacji i niemal wszystkie miały miesiączkę w tym samym czasie. Wówczas smród był większy niż ten z paraszy; strażnicy nie ociągali się, gdy mieli dyżur w naszej celi ${ }^{59}$.

Autorka wielokrotnie powtarza, że czuje, jakby jej ciało odzierano z godności zawsze wtedy, kiedy było brudne. Takie przeżycia, jak rewizja osobista czy golenie głowy po aresztowaniu, były przykre i niewątpliwie godziły w jej godność osobistą, ale na ich temat niemal się nie rozwodzi, jakby nie przywiązywała wagi do krótkich, pojedynczych incydentów, które dotykały każdej więźniarki. Tymczasem brudne ciało czy unoszący się w celi smród zdecydowanie częściej przyciągają jej uwagę. Po długich miesiącach dyskomfortu pozostała w niej trauma, która dawała o sobie znać nawet na wolności, gdy tylko pojawiały się przejściowe trudności z zachowaniem higieny - jak na przykład podczas długiej podróży: „kiedy się obudziłam, czułam się okropnie. Nie mogąc się przebrać czy umyć, przypomniałam sobie w tej chwili moją nieodległa przeszłość. Znowu to uczucie odczłowieczenia. Ale teraz mogę coś z tym zrobić”60.

Podczas pobytu w więzieniu czy na zesłaniu Ruth nie epatuje w sposób celowy swoją kobiecością, seksapilem młodej, pięknej dziewczyny, a przynajmniej nic nie pisze na ten temat. Raz tylko jeden wspomina, że postanowiła odwołać się do swojej urody i sławy jako atrybutów, które mogą pomóc odmienić jej tułaczy los - dzieje się tak, gdy po zakończeniu wyroku nie może osiąść na stałe w Moskwie, gdzie mieszka jej córka. Zdesperowana, składa wizytę wysoko postawionemu, pracującemu w jednej z ważnych instytucji państwowych w Moskwie oficerowi, który swego czasu był gorącym wielbicielem jej talentu i urody. Liczy na to, że pomoże jej zdobyć odpowiednie zezwolenie. Wizyta jednak nie przynosi oczekiwanych rezultatów, gdyż ów człowiek, wysłuchawszy relacji na temat bezdomności, braku środków do życia i przymusie bycia z dala od córki, z cyniczną obojętnością udziela okrutnej rady:

59 Turkow Kaminska, Mink Coats..., s. 141-142. Przekładu cytowanych w artykule fragmentów obcojęzycznych (z angielskiego i jidysz), o ile nie zostało zaznaczone inaczej - dokonała Magdalena Ruta.

${ }^{60}$ Tamże, s. 191. 
- Może mogłabym dostać pozwolenie tymczasowe, mogę coś zrobić w tym celu, zaapelować do właściwych władz. Naprawdę potrzebuję dachu nad głową. Chcę być z dzieckiem, przynajmniej przez chwilę.

- Zakazano.

- Może choć kilka dni? Jestem taka zmęczona. Nie czuję się dobrze.

- Zakazano.

- To może pan choć zasugerować, co mogłabym zrobić?

Ponownie patrząc przeze mnie, odpowiedział: - Jedyna rzecz, jaką mogę zasugerować, to iść i się powiesić.

Mówił to śmiertelnie poważnie. Podniosłam się i wykrztusiłam coś jak: - Proszę mi wybaczyć, że panu zawracałam głowę.

Poruszałam się jak marionetka, kupując bilet, wsiadając do pociągu i jadąc z powrotem do Riazania. Przeszło tydzień nie mogłam z nikim rozmawiać ani nawet zadzwonić do Doby [przyjaciółki opiekującej się córką Ruth - MR] ${ }^{61}$.

To jedno z niewielu miejsc w całej książce, kiedy Ruth odkrywa swoje emocje, w lakonicznym, ale poruszającym komentarzu informując, w jak trudnym stanie psychicznym znalazła się po tej rozmowie.

Doświadczenie kobiecości to również doświadczenie o charakterze erotycznym. Ruth nie ukrywa, że pobyt w więzieniu i odosobnienie to czas dla niej trudny nie tylko ze względu na samotność czy tęsknotę do matki i córki, ale także ze względu na niezaspokojone pragnienie bycia z mężczyzną. Samotność i trawiące ciało pożądanie dokuczały wszystkim kobietom w celi - świadectwem tego jest opowieść o incydencie, do jakiego doszło podczas świąt Bożego Narodzenia. Rut wspomina o swoistym rozluźnieniu, jakie wówczas tam zapanowało, o szukającym ujścia pragnieniu świętowania i zabawy. W pewnym momencie dwie młode dziewczyny Paula i Stefa - zaczęły ze sobą tańczyć w sugestywny sposób:

Najpierw kołysały się powoli, jakby na próbę. Wówczas kobiety zaczęły śpiewać głośniej i szybciej. Tancerki wzmogły tempo. Reszta coraz szybciej klaskała w dłonie. Stefa i Paula chwyciły się za ręce. Spojrzenia skierowały na siebie nawzajem. Paula zaczęła drzeć w ramionach Stefy, jej oczy płonęły, twarz poczerwieniała. Stefa zbladła, a jej ciemne oczy wpatrywały się uważnie w Paulę. Rytmiczne dźwięki, taniec i podniecenie zniosły ich zahamowania. Przestały zwracać na nas uwagę. Część kobiet, dręczona własnym niezaspokojonym pożądaniem, zaczęła jęczeć jak koty, inne łkały w niekontrolowany sposób, a pozostałe rzucały wulgarnymi sprośnościami ${ }^{62}$.

${ }^{61}$ Tamże, s. 231.

${ }^{62}$ Tamże, s. 143. 
Co ciekawe, temat przemocy seksualnej czy useksualizowanej jest we wspomnieniach Ruth nieobecny - być może autorka nie miała traumatycznych doświadczeń tego rodzaju albo też - co bardziej prawdopodobne zdecydowała się milczeć w tej sprawie.

Ruth odkrywa swoje kobiece oblicze również w tych fragmentach, w których ujawnia się jako córka, matka czy żona. Druga część wspomnieniowej narracji obraca się w dużej mierze wokół jej starań i zabiegów o to, aby - najpierw w więzieniu - dowiedzieć się, co się dzieje z córeczką po aresztowaniu jej i Adiego (podejmuje w tym celu strajk głodowy, co kończy się traumatyczną próbą przymusowego karmienia przez nos), a później na zesłaniu - aby zbudować taki dom, w którym mogłaby przyjąć Erike u siebie. Inny przykład - zagrożona utratą pieniędzy na rzecz kryminalnej więźniarki Jewdokii, którą dołączono do grupy aresztantek przewożonych pociągiem z jednego więzienia do drugiego, nie waha się zaryzykować, by obronić pieniądze będące gwarantem jej przyszłości z dzieckiem:

Myślałam o pieniądzach zaszytych w małym woreczku, który nosiłam; będę ich potrzebowała, aby skontaktować się ponownie z Dobą, Eriką, moją rodziną. Poza tym rzeczy, które muszę za nie kupić, mogą zadecydować o życiu lub śmierci w groźnej przyszłości, jaka stała przede mną. Mimo chłodu moje dłonie były lepkie i czułam na plecach zimny pot. [...]

Byłam pewna, że Jewdokia nie zauważyła mnie leżącej [wysoko - MR] na półce [...]. W ułamku sekundy postanowiłam zastosować się do maksymy, że najlepszą obroną jest atak. Wychyliłam się ku dołowi, resztką sił chwyciłam ją za klapy i runęłam z półki w dół. Z powodu odrętwiałej [chorej - MR] nogi ciało moje było sztywne i wydawało się cięższe.

Liczyłam na to, że na tyle zajmę jej uwagę, by inne kobiety mogły się na nią rzucić. [...] Po raz pierwszy w życiu posłużyłam się wszystkimi wulgaryzmami, jakie kiedykolwiek słyszałam - o których znajomość nawet siebie nie podejrzewałam. To mnie należało słuchać. To ja ustalałam zasady. [...]

Kiedy z powrotem wdrapałam się na moją grzędę, byłam cała mokra i cała drżałam ${ }^{63}$.

Niewątpliwie miłość do dziecka wyzwoliła w Turkow-Kamińskiej ogromne pokłady energii oraz odwagi i to doświadczenie dzieli ona z wieloma innymi kobietami, w tym z Olą Watową.

O swojej matce, wybitnej aktorce, Ruth wspomina wielokrotnie, od pierwszych stron, dając wyraz głębokiemu przywiązaniu, a także uwielbieniu dla niej jako artystki. Nie można przy tym uniknąć wrażenia, że liczne wzmianki o Idzie Kamińskiej służą wręcz budowaniu jej mitu jako aktorki

${ }^{63}$ Tamże, s. 155. 
i członkini królewskiej dynastii wybitnych aktorów, której Ruth jest spadkobierczynią. Ten zabieg występuje tylko w pierwszej części poświęconej życiu młodej Kamińskiej u boku wybitnego artysty Adiego Rosnera. Być może służyć miał zbudowaniu legendy samej Ruth, która czuła się nieco zdominowana przez sławnego męża?

Odpowiedzi na pytanie o rolę „wybranego innego" w odkrywaniu pisarskiej tożsamości Ruth Turkow-Kamińskiej poszukiwać należy przede wszystkim w tych miejscach, w których pojawia się ona w relacji do Adiego. To, co ich łączy, zmienia się w zależności od fazy pobytu w ZSRR. Faza pierwsza (przypadająca na okres wojny) to czas rozwoju kariery, bycia gwiazdą i żoną sławnego artysty, życia ponad stan. Ta część wspomnień przynosi wyidealizowany obraz Adiego - uwodziciela, człowieka szarmanckiego, hojnego, dbającego o ukochaną (pierwsza część tytułu nawiązuje do drogich prezentów, jakimi obdarzał żonę), kochanka idealnego, wspaniałego ojca. Ale zarazem - jak wyżej wspomniałam, Ruth buduje mit swojego dobrego pochodzenia, co ma pomóc jej uwypuklić własną wartość, nieco przyćmioną blaskiem ukochanego:

W ciągu tych kilku miesięcy, kiedy znaliśmy się przed wojną, on zawsze chciał dokonać rzeczy, która by mnie zachwyciła. Byłam jakby córką królewskiej rodziny teatru. Babka Estera Rachela Kamińska była tak znaną i tak ukochaną aktorką żydowską, że kiedy zmarła w 1926 roku, nawet nieżydowscy właściciele sklepów w Warszawie zamknęli swoje lokale, by dać wyraz żałobie. [...] Jej mąż, dziadek Abraham Izaak Kamiński, był aktorem, reżyserem, autorem sztuk i założycielem teatru Kamińskich, gdzie grała moja matka. Mój ojciec Zygmunt Turkow był dystyngowanym aktorem i autorem sztuk [...]. Jego bracia byli aktorami. [...] Drugi mąż mamy, Mel, był aktorem. Mama grała na scenie od dzieciństwa i została gwiazdą, mając szesnaście lat. Ja grałam w filmach jako siedemnastolatka. Byłam dziewczyną, która miała wszystko, więc Adi czuł się sfrustrowany ${ }^{64}$.

Symptomatyczne, że w drugiej fazie Ruth nie powraca już do rozważań na temat swojego dobrego rodowodu i rodzinnej opinii, iż związek z Adim to mezalians. Ta druga faza jest bowiem okresem rozdzielenia małżonków, samotności i pozornego upadku Ruth, która doświadcza oderwania od córki, uwięzienia, zesłania. Jednocześnie, jak się okazuje, jest to czas wyzwolenia się spod ograniczającego wpływu męża, odchodzenia od „wybranego innego”, kształtowania własnego „,ja”, dojrzewania, skupienia się już tylko na macierzyństwie (albo raczej próbie odzyskania możliwości przebywania z córką). Przemiana relacji między małżonkami

64 Tamże, s. 14. 
znajdzie swój finał w decyzji o rozstaniu - Ruth z córką opuszczają ZSRR, Adi zostaje. Narratorka zdawkowo wspomina o przyczynach odejścia od męża, mówiąc o jego „pękniętej” osobowości, która kazała mu się wdawać w liczne romanse, włącznie z poważniejszym związkiem w czasie zesłania jego owocem było dziecko. Najwyraźniej autorka czuje się zobowiązana wobec czytelnika, by jakoś wyjaśnić, dlaczego rozpadł się wręcz idealny związek z czasów estradowej świetności obojga. Jest przy tym bardzo lakoniczna, nie wdaje się w roztrząsanie szczegółów ani też nie szuka odwetu na niewiernym. Jak prawdziwa aktorka potrafi wyeksponować to, co błyszczące, chowając za kulisami to, czego widz nie powinien oglądać. W kontekście tych faktów symptomatyczna jest dedykacja umieszczona na początku wspomnień: „Pamięci Adiego Rosnera, wirtuoza trąbki, utalentowanego kompozytora, wspaniałego muzyka, niezwykłego showmana i ojca mojej córki”" ${ }^{65}$, w której podkreśla atrybuty byłego męża jako artysty oraz przypomina, że jest ojcem ukochanej córki Ruth, ale - co istotne - potwierdza także, iż przestał być mężem i kochankiem. Obecność „wybranego innego” - człowieka, z którym związek przyniósł owoce słodkie (córka, blaski życia gwiazdy) i gorzkie (więzienie, zesłanie) - była ważna na samym początku dorosłości Ruth i jej wspomnieniowej opowieści o tamtym czasie. Jednak gdy na pewnym etapie tej wielkiej narracji, jaką jest życie, obecność ta utraciła swoje znaczenie, to również w tej małej narracji, jaką jest opowieść o życiu, przestała być ważna, choć przecież miała do spełnienia ważną funkcję - katalizatora procesu twórczego. Pisanie wspomnień otwiera przed Ruth Turkow możliwość przekonania czytelnika i samej siebie, że od samego początku była osobowością równą Adiemu, a jeśli zdarzyło się jej wejść w rolę „niewidzialnej asystentki”, to tylko z powodu (niezależnych od niej) uwarunkowań biologicznych, gdy została matką i przez krótki czas sama zajmowała się wychowaniem dziecka, dzięki czemu on mógł kontynuować karierę. W miarę upływu lat i zdobywania doświadczeń córka zajmuje w jej życiu miejsce męża. Od pewnego momentu opowieść toczy się już nie dzięki niemu, lecz niejako w opozycji do człowieka, który przez kilka lat kształtował życie dziewiętnastoletniej, niedoświadczonej, wręcz naiwnej dziewczyny, jak sama siebie prezentuje na początku swoich wspomnień. Ruth Turkow-Kamińska jako autorka wspomnień jest już dojrzałą, niezależną i świadomą swoich możliwości kobietą-artystką, która z rozmysłem pracuje na swoje nazwisko.

${ }^{65}$ Tamże. 


\section{Moja droga przez mękę z Mojszem Broderzonem}

Autorką kolejnych wspomnień jest Sonia Broderzon ${ }^{66} \mathrm{z}$ domu Mandelbaum (1903 - ok. 1985 [1977-1986]), pseudonim artystyczny Szejna-Miriam - tancerka, aktorka, pianistka, żona wybitnego poety jidyszowego, malarza i rysownika Mojszego Broderzona (1890-1956). Dzieło pt. Majn lajdns-weg mit Mojsze Broderzon. Di milchome hot gedojert far undz zibecn jor... (Zichrojnes) [Moja droga przez mękę z Mojszem Broderzonem. Wojna trwała dla nas 17 lat... (Wspomnienia) $]^{67}$ zostało wydane w Buenos Aires w roku 1960 w znanej serii „Dos pojlisze Jidntum”68 pod nr. 153. Szejna-Miriam spisała wspomnienia i wydała w języku jidysz zaledwie cztery lata po śmierci męża. Tytuł, w którym pojawia się nazwisko tego znanego poety, a także seria, w jakiej się ukazały, świadczą o tym, że były one przeznaczone dla zamkniętego grona odbiorców. Dowodem na to jest także sposób, w jaki Szejna-Miriam zwraca się do swojego czytelnika - zorientowanego w świecie żydowskiej literatury i kultury w Europie Środkowo-Wschodniej, znającego najnowsze dzieje Żydów polskich i losy inteligencji żydowskiej w ZSRR, a więc czytelnika, któremu nie trzeba niczego objaśniać. Jak sama stwierdza, zaczęła pisać, by zaświadczyć o koszmarze, który spotkał żydowskich lekarzy i przedstawicieli inteligencji żydowskiej w latach stalinizmu, a także by wezwać do ujawnienia prawdy i wymierzenia sprawiedliwości wszystkim winnym zbrodni. Uznała, że jako świadek ma zobowiązanie wobec ofiar zbrodni stalinowskich - zbrodni, które nie były dziełem przypadku, lecz - jak się domyślała pod koniec lat pięćdziesiątych - zaplanowaną akcją zmierzającą do likwidacji żydowskich artystów i pisarzy:

${ }^{66} \mathrm{~W}$ internecie nie ma po niej śladu - poza zapisem na portalu Geni.com: Sonia (Sheine Miriam) Broderson (Mandelbaum), https://www.geni.com/people/Sonia-Broderson/6000000010963535561 [dostęp: 13 lipca 2021]. W ogólnodostępnych zasobach nie znalazłam ani jej biografii, ani fotografii, a poszukiwania w wyszukiwarce Google prowadziły mnie nieodmienne do Mojszego Broderzona.

${ }^{67}$ Szejne-Miriam Broderzon, Majn lajdns-weg mit Mojsze Broderzon. Di milchome hot gedojert far undz zibecn jor... (Zichrojnes), Buenos Aires 1960.

${ }^{68}$ W latach 1946-1966 ukazywała się w jidyszowym wydawnictwie w Buenos Aires ważna seria książkowa zatytułowana „Dos pojlisze Jidntum”, w ramach której publikowano książki wspomnieniowe poświęcone przedwojennemu życiu żydowskiemu w Polsce, ale i świadectwa Zagłady czy wreszcie wiele pozycji o doświadczeniu sowieckiego uchodźstwa i zsyłki do łagrów. Więcej o tej serii zob. Jan Schwarz, Survivors and Exiles: Yiddish Culture after the Holocaust, Detroit 2015. Tu: rozdz. 4 - Dos poylishe yidntum: A Library of Hope and Destruction, s. 92-117. 
Ja, żywy świadek koszmarnego, antysemickiego, morderczego szaleństwa, nie przestanę się domagać od spadkobierców Stalina, aby ujawnili przed światem sposób i stalinowską planowość przy realizacji niesłychanej, straszliwej zbrodni przeciw żydowskim pisarzom i działaczom kulturalnym. Nie przestanę się domagać, aby winni straszliwych mordów - donosiciele, naczelnicy-enkawudziści, sadystyczni śledczy, sędziowie w togach sprawiedliwości, po ostatnich katów, którzy niewinnych męczenników prowadzili na rozstrzelanie - zostali postawieni przed publicznym trybunałem i ukarani jako mordercy i sadyści... ${ }^{69}$.

Ofiarą tego zła padł również jej mąż, nic więc dziwnego, że pisząc te słowa, autorka ujawnia żywe emocje. Prawdopodobnie spisanie wspomnień - poza nagłośnieniem tragedii - mogło być też działaniem terapeutycznym.

Wspomnienia Szejny-Miriam to dokument epoki, a także świadectwo miłości i poświęcenia dla bliskiego człowieka, jakim był jej mąż. Warto na marginesie dodać, że choć była również matką, to z nieznanych przyczyn wspomina o tym zaledwie w kilku miejscach, na przykład wówczas, gdy opowiadając o wybuchu wojny, informuje, że po ewakuacji męża została sama z córką (która miała wówczas dziewiętnaście lat ${ }^{70}$, czyli była rówieśnicą Ruth Turkow). Jej opowieść obejmuje siedemnaście lat (1939-1956) i zawiera zarówno zapis tego, co spotkało ją i męża po ucieczce z Łodzi do zajętego przez Sowietów Białegostoku, jak i późniejszych losów, kiedy po wojnie zdecydowali się pozostać w Moskwie. Przebieg wydarzeń z tego okresu ilustruje następujące kalendarium:

- jesień 1939 - ucieczka Szejny-Miriam i Mojszego z Łodzi do Białegostoku (wcześniej ona przebywa krótki czas w Warszawie);

- październik 1939 - czerwiec 1941 - ewakuacja obojga w głąb ZSRR (Turtkul w Karakałpacji / Uzbekistan);

- 1944 - powrót przez ukraiński kołchoz na Zaporożu do Moskwy;

- kwiecień 1950 - aresztowanie Mojszego, dziewięciomiesięczny pobyt w więzieniu w Moskwie;

- styczeń 1951 - wyrok skazujący na dziesięć lat łagrów;

- 1951-1955 - pobyt w łagrze (Nowoczółka k. Irkucka);

- wrzesień 1955 - powrót do Moskwy, spotkanie z żoną;

${ }^{69}$ Broderzon, Majn lajdns-weg..., s. 51.

${ }^{70}$ Informację o przybliżonej dacie śmierci Szejny-Miriam, a także o istnieniu jedynej córki jej i Mojszego - Anny Burstyn (30 sierpnia 1920 - ok. 2010), znalazłam na cytowanym już portalu Geni.com: Sonia (Sheine Miriam) Broderson... Sama Szejna-Miriam, wyliczając, jak skrzywdziła ją wojna, wspomina o śmierci bliskich, w tym ojca, ani słowem nie odnosząc się do losów córki. 
- czerwiec 1956 - wyjazd małżonków do Polski, osiedlenie się w Warszawie;

- 17 sierpnia 1956 - śmierć poety w Warszawie;

- 1957 - spisywanie wspomnień;

- styczeń 1957 - wyjazd Szejny-Miriam do Izraela ${ }^{71}$.

Lata 1939-1946 opisane są w sposób skrótowy na zaledwie czterdziestu stronach, a relacja przynosi zwięzłą informację o ucieczce z okupowanej Łodzi do Białegostoku i życiu zawodowym Broderzona (praca w teatrze miniatur w Białymstoku, tournée z trupą teatralną po ZSRR), a także o atmosferze, jaka panowała wówczas w mieście i w środowisku żydowskich pisarzy-uchodźców z Polski, oraz daje zwarty zarys dalszych losów małżeństwa po wybuchu wojny niemiecko-radzieckiej (ewakuacja do miasta Turtkul nad Amu-darią w Karakałpacji). Kolejne sto trzydzieści trzy strony to opowieść o dekadzie 1946-1956, na którą składały się dwa etapy. Po pierwsze - okres względnie spokojnego życia w powojennej Moskwie (1946-1950), które jednak, pomimo pozorów stabilizacji, wypełnione było walką Szejny-Miriam o zdrowie fizyczne i psychiczne męża. Ten bowiem, gdy dowiedział się o Zagładzie, niezwykle przygnębiony odmówił powrotu do Polski, „[z]łamanym głosem mówiąc: »Nie mogę osiedlić się na cmentarzu «"72. I wreszcie po drugie - zajmująca najwięcej miejsca relacja z lat 1950-1956, które były czasem walki o jego życie, gdy po dziewięciomiesięcznym pobycie $\mathrm{w}$ areszcie został skazany na dziesięć lat łagru.

Z tytułu wspomnień wynika, że opowieść Szejny-Miriam jest poświęcona mężowi i cierpieniom, przez jakie ona sama przeszła wraz z nim. Jednak już od pierwszych stron wzrok narratorki skupiony jest przede wszystkim na nim - jej „wybranym innym”. Wygląd, zachowanie, reakcje i poglądy Broderzona są ważniejsze niż to, co dzieje się z nią samą. W pierwszej części, kiedy wciąż jest fizycznie obecny przy niej, autorka powstrzymuje się od prezentowania swoich poglądów, skupiając się głównie na tym, co myśli i sądzi mąż. Jej poglądów możemy się domyślać jedynie na podstawie przywoływanych sądów opinii społecznej, które zdaje się podzielać - na przykład gdy wspomina o powszechnej krytyce pod adresem pewnego pisarza, który, uciekając się do donosicielstwa, podjął współpracę z nowym

${ }^{71}$ Zob. artykuł Broderzon's almone gekumen kejn Isroel, „Forwerts” (8 stycznia 1957): https://www.nli.org.il/en/newspapers/frw/1957/01/08/01/article/7/?e=-------en-20--1--imgtxIN $\% 7 \mathrm{ctxTI}$ -1 [dostęp: 13 lipca 2021].

${ }^{72}$ Broderzon, Majn lajdns-weg..., s. 40. 
reżimem w nadziei na łatwą karierę ${ }^{73}$. Szejna-Miriam bardzo często oddaje Broderzonowi głos, nie tylko relacjonując jego wypowiedzi, dowcipy i błyskotliwe, ironiczne komentarze, ale też obficie cytując z jego pism - wierszy i listów. Są one świadectwem stanów emocjonalnych, jakich wówczas doświadczał (por. ocalony przez Szejnę-Miriam utwór Ojf undzer churbm [Na naszych ruinach] z roku 1946) ${ }^{74}$. Z jej relacji wynika, że gdy tylko dowiedział się o zbrodni przeciwko Żydom polskim, popadł w głęboką depresję. Jeszcze w zaporoskim kołchozie, gdzie małżonkowie przebywali przez jakiś czas w 1944 r. w drodze do Moskwy, dowiedziawszy się o współudziale Ukraińców w zbrodniach przeciwko Żydom, Broderzon przeżył rodzaj załamania. Miriam pisze:

Całe trzy miesiące, które spędziliśmy w kołchozie, Broderzon nie wychodził z pokoju. Nie chciał spotykać się z ukraińskimi chłopami. Mówił, że przed jego oczyma unoszą się dziesiątki tysięcy zamęczonych Żydów, zamordowanych przez Ukraińców od czasów Chmielnickiego aż po ostatnie pogromy.

Byłam mocno zaniepokojona przygnębieniem Mojszego ${ }^{75}$.

Z kolei już po wojnie, gdy po repatriacji przyjaciół-pisarzy został w Moskwie sam, cierpiał podwójnie. Szejna-Miriam komentuje: „Cień smutku unosił się nad jego pociaggą twarzą, która zdawała się robić coraz dłuższa i coraz bardziej zamknięta, z głębokimi zmarszczkami uporu w kącikach ust" ${ }^{\text {"6 }}$. Sytuacji emocjonalnej nie poprawiła zagęszczająca się atmosfera wrogości wobec Żydów po śmierci wybitnego żydowskiego aktora Szlojmego Michoelsa ani aresztowania radzieckich pisarzy języka jidysz, które nastąpiły niedługo potem, bo już w 1948 r. Szejna-Miriam tak pojmowała wówczas swoje zadanie: „Chociaż i ja nosiłam wówczas w sercu jak on tę samą gorycz i rozpacz, to jednak próbowałam uspokoić go, pocieszyć, jak to mówią, łagodnym sercem"'77. Przygnębiony poeta przestał opuszczać mieszkanie, oddając się lekturze świętych ksiąg judaizmu, które kupił na pchlim targu. Wspominając o tym, żona podkreśla, że choć Broderzon nie był religijny, to zachwycał się zawartym w nich przesłaniem etycznym i moralnym, zwłaszcza w obliczu tego, co się wówczas działo w Moskwie:

\footnotetext{
73 Tamże, s. 21.

74 Tamże, s. 44-45.

75 Tamże, s. 38.

76 Tamże, s. 46.

77 Tamże, s. 54.
} 
W tamtych strasznych czasach Broderzon jeszcze bardziej zagłębił się w swoich księgach. Często czytywał mi jidyszowe przekłady, podziwiając wysokie ideały etyczne oraz poetycką fantazję, którą pobożni autorzy ujawniali w swoich dziełach. „Tam zapisane są wieczne ideały moralne, które mają znaczenie i w naszych czasach, i w naszych warunkach człowieczego upadku" - mówi ${ }^{78}$.

Po jego śmierci Szejna-Miriam zabrała księgi ze sobą do Izraela jako ważną pamiątkę ${ }^{79}$.

Autorka wielokrotnie i wprost wyraża miłość i przywiązanie do Mojszego, jak na przykład wówczas, gdy stwierdza, iż decyzję o ucieczce z Warszawy (gdzie zatrzymała się po opuszczeniu Łodzi) do Białegostoku, gdzie wcześniej dotarł jej mąż, pomogła jej podjąć tęsknota za człowiekiem, z którym nie rozstawała się przez ostatnie dwadzieścia lat. Lejtmotywem wspomnień jest troska o jego zdrowie i życie, przekonanie, że musi go chronić, bo jest człowiekiem bardzo wrażliwym i delikatnym, niezwykle podatnym na stres. Autorka przedstawia go jako bliskiego duchowo przyjaciela (chociaż mniej tu sygnałów o porozumieniu intelektualnym, którym emanuje opowieść Watowej), ale też podkreśla jego walory fizyczne, dyskretnie sygnalizując fascynację urodą i elegancją męża. Warto w tym miejscu podkreślić, że w jej opowieści nie ma wyrażonych wprost wątków związanych z cielesnością czy seksualnością, można się jednak domyślać, iż $\mathrm{i}$ ten aspekt w jej życiu był ważny. Refleksja, jak bardzo samotna czuje się po aresztowaniu męża i jak jej smutno w pustym mieszkaniu - i w pustym łóżku - może być tego dyskretnym potwierdzeniem ${ }^{80}$.

Kiedy na przełomie lat 1947 i 1948 rozpoczęły się w Moskwie aresztowania żydowskich intelektualistów i pisarzy, Broderzonowie żyli w napięciu, spodziewając się wizyty NKWD. Szejna-Miriam wspomina, że często zastanawiała się wówczas, co będzie, gdy „Oderwą ode mnie mojego jedynego przyjaciela i zostanę sama na tym świecie pełnym trwogi i rozpaczy"81. Mimo napiętej atmosfery i strachu nie poddaje się jednak zwątpieniu, próbując uspokoić i pocieszyć męża ${ }^{82}$. Wówczas też staje się jedyną żywicielką rodziny, podejmując pracę w kombinacie dla bezrobotnych aktorów i pisarzy żydowskich, gdzie zatrudnione były same kobiety, których mężowie zostali aresztowani. Każda z nich miała serce złamane,

\footnotetext{
78 Tamże, s. 61.

79 Tamże, s. 60.

80 Tamże, s. 94.

81 Tamże, s. 59.

82 Tamże, s. 53-55.
} 
ale wszystkie bały się o tym mówić8 ${ }^{83}$. Szejna rozumie ich obawy, jednak zadziwia ją to, że nie podejmowały żadnych wysiłków, aby dowieść niewinności swoich mężczyzn i walczyć o ich zwolnienie. Nie robiły nic, bo wiedziały, że cokolwiek zrobią, to i tak nic nie da - więc „,czekały na cud”84. Autorka wielokrotnie zauważa, że ludzie w ZSRR, bardzo doświadczeni przez komunistyczną władzę, przyjmowali wszystko bez buntu, niemal jako dopust boży ${ }^{85}$. Podkreśla przy tym różnicę między nimi a sobą - zbyt niecierpliwą, aby bezczynnie czekać, wychowaną w innej kulturze, która uczyła ufności w moc prawa:

Tylko ja jedna, która wyrosłam w środowisku wierzącym w moc prawa, moralności i etyki, stoję teraz w pięknie wymytym korytarzu przed zamkniętymi drzwiami z mosiężnymi tabliczkami, na których wypisano nazwiska prokuratorów, i nie wiem, do kogo mam się zwrócić86.

I nawet gdy po aresztowaniu męża doświadcza załamania nerwowego, po czterech ciężkich dobach zbiera siły i rozpoczyna uporczywą, wieloletnią wędrówkę w poszukiwaniu sprawiedliwości. „Gdy tylko nieco przyszłam do siebie, zaczęłam się zastanawiać, co dalej? Jak uratować Mojszego" ${ }^{87}$.

Większa część wspomnień Szejny-Miriam (strony 71-173) to opowieść o walce, jaką stoczyła, najpierw domagając się widzenia z przebywającym w moskiewskim więzieniu mężem, później prosząc o możliwość dostarczenia mu paczek, pieniędzy i ciepłych ubrań, upominając się o rewizję wyroku i wreszcie czyniąc starania o jego rehabilitację. To też opowieść o niezliczonych upadkach i nieustannym podnoszeniu się, historia traumy, poważnego zapadania na zdrowiu, samobójczych myśli. Jednak Szejna-Miriam, choć boleśnie doświadczana przez los, szybko odrzuca od siebie pokusę ostatecznego rozwiązania poprzez samobójstwo:

„Jego życie się skończyło, on tego nie przetrzyma, to po co ja mam żyć i się męczyć?" Jednak wkrótce porzuciłam straszliwą myśl i doszłam do wniosku, że

${ }^{83}$ Tamże, s. 56.

${ }^{84}$ Tamże, s. 57-58.

${ }^{85}$ Tamże, s. 53, 71. Uwagi (zapewne w wielu przypadkach krzywdzące) o bierności mieszkańców Związku Radzieckiego, która miała być reakcją na wieloletni terror w kraju totalitarnym, czy też refleksje na temat ich naiwnej wiary w to, co głosiła sowiecka propaganda, pojawiają się stosunkowo często w prozie łagrowej pisarzy języka jidysz, np. Jenty Masz, Awroma Zaka czy przywoływanej wcześniej Ruth Turkow-Kamińskiej.

${ }^{86}$ Tamże, s. 81.

${ }^{87}$ Tamże, s. 71. 
„Muszę żyć dla niego, pracować, aby ulżyć jego ciężkiemu losowi. Może jednak zdarzy się cud i ta zbrodnia przeciw niewinnemu człowiekowi się skończy"88.

A zatem jej relacja to kolejne po wspomnieniach Oli Watowej i Ruth Turkow-Kamińskiej świadectwo tego, jak obawa o losy bliskich, tych „wybranych innych”, staje się źródłem siły, by się nie poddać i walczyć o przetrwanie dla ich dobra.

Odwiedzając Ministerstwo Bezpieczeństwa Wewnętrznego oraz Prokuraturę Wojskową w Moskwie, Szejna-Miriam miała okazję spotkać wiele kobiet, które próbowały się dowiedzieć czegoś o losach swoich mężów. Jej uwagę zwraca to, że odważyły się rozpocząć aktywne poszukiwania dopiero po śmierci Stalina, kiedy pojawiła się nadzieja na złagodzenie kursu politycznego. Przy okazji poznała wiele tragicznych historii. Na ich marginesie zauważa, że areszt i zsyłka to nie tylko dramat więźnia, to nieszczęście, które dotyka całą jego rodzinę. Niektóre żony, tracąc nadzieję na powrót mężów, poddawały się i godziły na rozwód (wspomina o tym jako o powszechnym zjawisku też Ruth Turkow, choć sama podkreśla swoją lojalność w trudnych chwilach wobec - było nie było - niewiernego Adiego). Inne z kolei decydowały się pracować ponad siły, aby utrzymać osieroconą rodzinę. Te tragedie to według Szejny-Miriam żywy materiał na przejmującą powieść psychologiczną. Gdy jej mąż po niemal roku spędzonym w więzieniu zostaje skazany w styczniu 1951 r. na dziesięć lat łagrów, postanawia, że będzie na niego czekać, a po zakończeniu kary pojedzie z nim wszędzie tam, gdzie mu nakażą władze.

Szejna-Miriam zaczęła pisać, by opowiedzieć o losie, jaki dotknął przede wszystkim jej męża, a przy okazji również i ją. Ten szczególny cel widoczny jest na przykład w pieczołowitości, z jaką zbierała i odtwarzała szczegóły jego pobytu w łagrze, choć on sam nie chciał zbyt wiele o tym mówić. Dlatego też rozdział poświęcony jego doświadczeniom łagrowym powstał dzięki informacjom zdobytym od kogoś, kogo poznała dopiero w Izraelu już po śmierci Mojszego. Jej relacja przynosi drobiazgowy, pełen współczucia portret nadwrażliwego intelektualisty żydowskiego, który dostawszy się w tryby historii, zostaje zniszczony zarówno w wymiarze psychicznym, jak i fizycznym. Przy okazji, niejako mimochodem, opowiada też o sobie - niezłomnej towarzyszce jego drogi życiowej. I choć niemal cały czas pozostaje $\mathrm{w}$ jego cieniu, $\mathrm{z}$ rozsianych tu i ówdzie uwag można wywnioskować, że jest świadoma swoich mocnych stron, wie, iż może na sobie

${ }^{88}$ Broderzon, Majn lajdns-weg..., s. 85. 
polegać. „Siła opanowania, niepokazywania ludziom prawdziwego oblicza, które budzi litość, ta siła, która towarzyszy mi przez całe życie - również i teraz mi pomogła" ${ }^{99}$ - pisze, relacjonując pierwsze chwile po aresztowaniu męża. To ona, jedyna z całej trójki autorek wspomnień, najlepiej wpisuje się w rolę „niewidzialnej asystentki”, perfekcyjnie - i niemal dosłownie, jeśli weźmiemy pod uwagę jej „niewidzialność” w Internecie - skrywającej się w cieniu wybitnego mężczyzny, i to pomimo sukcesów, jakie odnosiła przed wojną jako aktorka i tancerka. Ze wspomnieniowej narracji wyłania się jej obraz jako osoby, która była nie tylko jego przyjaciółką, powiernicą, słuchaczką i czytelniczką, ale przede wszystkim prawdziwą ostoją, i to w każdym wymiarze - tak duchowym, jak i materialnym, a po śmierci została strażniczką pamięci o nim.

\section{Kilka refleksji na podsumowanie}

Olę Watową, Ruth Turkow-Kamińską i Szejnę-Miriam Broderzon połączył wspólny los - los pewnego pokolenia Żydówek polskich, żon i matek, ocalałych z Zagłady dzięki uchodźstwu, którym czas spędzony w ZSRR nie tylko ocalił życie, ale też przyniósł dotkliwe cierpienie. Chęć zmierzenia się z tym losem stała się dla nich bezpośrednim bodźcem, aby sięgnąć po pióro. Traumatyczne doświadczenia wszystkie trzy autorki dzieliły ze swoimi wybitnymi mężami. Te dwa czynniki były więc konstytutywne dla ich procesu pisarskiego - bliskość „wybranego innego” oraz trauma. „Związek z drugą autonomiczną istotą"90 - źródło aktu twórczego - miał jednak w każdym przypadku inne przesłanki i inne konsekwencje.

Pisanie Oli Watowej to realizacja testamentu męża, który przewidział dla niej takie zadanie, ale to również próba przemówienia własnym głosem, wyjścia w sferę publiczną. To rozpoznanie i realizacja woli człowieka, którego kochała i który ją fascynował, ale też okazja, by zawalczyć o odrębność własnego istnienia jako twórczyni - o czym świadczy opisana wcześniej walka o autorstwo książki ${ }^{91}$.

89 Tamże, s. 79.

90 Mason, Inny głos..., s. 291.

${ }^{91}$ Co ciekawe, autoryzowane przekłady wspomnień na języki obce noszą tytuł „Drugi cień”, bo, zdaniem Jana Zielińskiego, Ola Watowa żyła w cieniu męża, a jej wspomnienia są wyrazem wierności temu cieniowi. Zob. Jan Zieliński, Ola Watowa, „Culture.pl” (październik 2009): https://culture.pl/pl/tworca/ola-watowa [dostęp: 14 lipca 2021]. 
Wspomnienia Ruth Turkow-Kamińskiej są nie tylko świadectwem traumy związanej z pobytem w sowieckich więzieniach i na zesłaniu, ale także rodzajem rozliczenia z początkami dorosłego życia. Jej pisanie początkowo stoi pod znakiem „wybranego innego”, jednak z czasem rozwija się w kontrze do jego silnej osobowości, która odcisnęła wyraźne piętno na życiu autorki jako kobiety, młodej aktorki i matki. Wspomnienia są świadectwem procesu wyzwalania się, poszukiwania źródeł własnego blasku, dojrzewania do samodzielności tak w życiu, jak i na scenie. A także zmiany tej wybranej osoby, jaka się dokonała, gdy ona jako matka skupiła całą swoją uwagę tylko na córce.

Z kolei wspomnienia Szejny-Miriam - osoby w pełni aprobującej rolę „niewidzialnej asystentki”, która najbardziej z całej trójki chowa się w cieniu męża - trzeba traktować jako wyraz, jakże dla niej typowej, macierzyńskiej troski o najbliższego człowieka, i to pomimo - a może właśnie z powodu! - jego śmierci. To także swoista próba zadośćuczynienia za krzywdy, których doznał, a od których nie potrafiła go ustrzec. Stąd detaliczna o nich opowieść i dbałość, by mogli je poznać ci, którzy go znali i pamiętali.

Przywołana na wstępie artykułu teza Mary G. Mason znajduje potwierdzenie w przeanalizowanych tekstach wspomnieniowych. Każdy z nich jest zapisem jedynej w swoim rodzaju relacji autorki z „wybranym innym”, dzięki której mogła ona odkryć własne ja i opowiedzieć historię tego odkrywania. Trzeba jednak przyznać, że autobiografie te są przykładem dość specyficznym, gdyż opowiadają o losach kobiet, które w trudnych dla siebie okolicznościach życiowych (wojna, zesłanie, tułaczka po kraju o opresyjnym ustroju politycznym) pozostawały w bliskim (i udanym) związku z mężczyznami wybitnymi. Aby jednak znaleźć odpowiedź na pytanie, czy diagnoza Mason dotyczy pisarstwa autobiograficznego innych (wszystkich?) autorek żydowskich, należałoby przeprowadzić pogłębione badania nad różnorodnymi tekstami wspomnieniowymi - pisanymi w odmiennych okolicznościach historycznych i przez kobiety o różnym statusie życiowym itd. Ciekawa mogłaby być również analiza wspomnień mężczyzn pozostających w związku z wybitnymi i znanymi kobietami, gdyż mogłaby ostatecznie zweryfikować tezę, która stała się punktem wyjścia niniejszych rozważań.

Omówione wspomnienia doskonale wpisują się w zrekonstruowany przez Estelle Jelinek model wspomnień kobiecych. Również i w tym przypadku przebadanie większego korpusu tekstów autorstwa żydowskich 
kobiet i mężczyzn pozwoliłoby odpowiedzieć na pytanie, czy jej ustalenia na temat różnic między autobiografiopisarstwem kobiecym a męskim, które odnoszą się do wspomnień powstających w kręgu kultury zachodniej, są aktualne także dla narracji Żydów i Żydówek. Bez wdawania się w pogłębione analizy warto w tym miejscu podkreślić, że najważniejszą i najbardziej rzucającą się w oczy różnicą między żydowskimi autobiografiami męskimi a kobiecymi jest zanurzenie narracji męskiej w systemie myślenia ukształtowanego przez obejmujące tylko chłopców tradycyjne szkolnictwo religijne i studia nad pismami świętymi - Torą i Talmudem ${ }^{92}$. Jest to jednocześnie cecha wyraźnie odróżniająca męską autobiografistykę żydowską od nieżydowskiej. Na wszechstronne opisanie tego, czym jeszcze różnią się między sobą autobiografie pióra Żydów i Żydówek, a także jak różnice te mają się do ustaleń badaczy zajmujących się wspomnieniami przedstawicieli świata zachodniego, trzeba jeszcze poczekać.

Warto na marginesie zauważyć, że z omawianych tekstów (także ze wspomnień wielu innych Żydów i Żydówek polskich) wyłania się zbliżony obraz stosunku do Rosji i Rosjan. Wydaje się on wewnętrznie sprzeczny, bo z jednej strony składa się nań (artykułowane jeszcze przed ucieczką na Wschód oraz na samym początku pobytu w ZSRR) przychylne nastawienie wobec państwa sowieckiego, postrzeganego jako eksperyment wcielający w życie ideę komunizmu, a z drugiej - pełen uprzedzeń stosunek do Rosjan i Żydów rosyjskich, a zwłaszcza do funkcjonariuszy komunistycznego reżimu. Pozytywne spojrzenie na ZSRR jest typowe dla wspomnień wielu Żydów polskich, zwłaszcza o lewicowych sympatiach, którzy jesienią 1939 r. podjęli decyzję o ucieczce na Kresy, wyobrażając sobie, że zostaną serdecznie przyjęci w kraju, gdzie antysemityzm został pokonany - i to odróżnia ich refleksje od bodaj większości wspomnień Polaków. Nie da się jednak zaprzeczyć, że obowiązujący w II Rzeczypospolitej negatywny obraz Rosji i Rosjan, zbudowany na tradycyjnej polskiej rusofobii, strachu przed bolszewizmem i antyrosyjskim wychowaniu patriotycznym, wycisnął swoje piętno na świadomości każdej z przywołanych tu autorek (a także wielu innych autorów pochodzenia żydowskiego ${ }^{93}$. Widać to wyraźnie w niemal identycznych uwagach dotyczących różnic mentalnych między nimi - reprezentantkami Zachodu - a mieszkańcami sowieckiej Rosji,

${ }_{92}$ Niniejsza uwaga zrodziła się w toku mojej dyskusji z Joanną Lisek, której niniejszym dziękuję za inspirację. Ogólne uwagi na temat specyfiki autobiografii w języku jidysz można znaleźć w: Schwarz, Imagining Lives..., s. 3-22.

${ }^{93}$ Więcej na ten temat zob.: Sucharski, Polskie poszukiwania „innej” Rosji... 
pełnym uprzedzeń stosunku do żołnierzy Armii Czerwonej okupującej polskie miasta kresowe, podobnej niechęci do sowieckich urzędników i funkcjonariuszy, swoistym poczuciu wyższości nad biernymi, straumatyzowanymi komunistycznym terrorem Rosjanami lub radzieckimi Żydami czy wreszcie w pozytywnym odkrywaniu „innej” Rosji, Rosji ludzi dobrych, życzliwych i wartościowych, które dokonywało się dzięki wspólnocie cierpienia. Ten rys, mający wiele wspólnego ze wspomnieniami Polaków, jak również przywołane nieco wcześniej cechy charakteryzujące stosunek do ZSRR i Rosjan zapisane w omawianych tu autobiografiach (a także podkreślmy - w autobiografiach wielu innych Żydów i Żydówek polskich) bez wątpienia warte są odrębnej uwagi ${ }^{94}$.

W przywoływanym tu wcześniej artykule Centralna płeć cywila, analizującym zapis kobiecego doświadczenia w ekstremalnej sytuacji wojennej lub okołowojennej, Inga Iwasiów posługuje się kategorią „dobrej kobiecości”, aby scharakteryzować zjawisko przypisywania wyższości moralnej kobietom o tej samej przynależności narodowo-etnicznej, czyli „swoim”. Badaczka zauważa, że:

Jedną ze strategii przetrwania jest stworzenie kategorii „dobrej kobiecości”, która wyróżnia i tym samym ochrania kobiety przetrzymywane w ekstremalnie trudnych warunkach. Ta „dobra kobiecość” łączy patriarchalną dyrektywę drogocenności „naszych kobiet” ze wspólnotowymi procesami zachodzącymi w grupie jednorodnej płciowo ${ }^{95}$.

Ze względu na brak miejsca na szczegółową analizę wypada tu jedynie zasygnalizować (nie)obecność tego wątku w omawianych wspomnieniach (chociaż i ta kwestia zasługuje na osobną refleksję). Żadna z autorek, mimo najrozmaitszych perypetii życiowych w sowieckich więzieniach, na zesłaniu i w sowieckim społeczeństwie, nie doświadczyła takiej sytuacji, w jakiej obserwuje swoje bohaterki Iwasiów - tzn. życia w zamkniętej, jednorodnej płciowo społeczności, w której obok przedstawicielek innych narodowości byłaby też obecna duża grupa „swoich”, tj. Żydówek. Jeśli więc można dostrzec $\mathrm{w}$ toku narracji tworzenie się pewnych podziałów na narody „lepsze” i „gorsze”, to przebiegają one siłą rzeczy inaczej niż

${ }^{94}$ Oprócz Oli Watowej, Ruth Turkow-Kamińskiej i Szejny-Miriam Broderzon można tu wymienić takich autorów wspomnień uchodźczych, którzy reprezentują podobne podejście do ZSRR (pozytywne z początku), ludzi sowieckich (negatywne) i do narodu rosyjskiego (pozytywne), jak np.: Awrom Zak, Mojsze Grosman, Mojsze Szklar, Jerzy Edison, Jerzy Gliksman. Na temat wspomnień Awroma Zaka zob. Ruta, "We were slaves"...

${ }^{95}$ Iwasiów, Centralna płeć cywila..., s. 410. 
w przypadku opisywanym przez Iwasiów. Żadna z trzech wspominających kobiet nie miała możliwości, aby w opowieści ulokować siebie pośród „swoich”, bo tych „swoich” po prostu nie było w danych okolicznościach. Z narracji Oli Watowej, która została zesłana wraz z grupą Polaków, wynika, że przez cały czas (lub przez jego większość) była na zesłaniu jedyną Żydówką. Ze strony wielu rodaków doświadczyła wówczas żywych antysemickich resentymentów. Watowa wielokrotnie to podkreśla, bardzo krytycznie wypowiadając się o towarzyszących jej na zesłaniu Polkach i Polakach, a w opozycji do nich (a także Rosjan) lokuje naród Kazachów, których zdaje się wręcz idealizować. A przecież punktem odniesienia dla jej świadomości wciąż i nieustannie pozostaje żywa kultura polska, nie stroni także od przyjaźni z przedstawicielami narodu polskiego (by wspomnieć tu choćby - również idealizowaną - Stefanię Skwarczyńską). Ruth Turkow również nie wskazuje „swojej” grupy etnicznej, z którą mogłaby się utożsamiać. W jej przypadku grono Żydów i Żydówek, w którym się obracała przed aresztowaniem, zapewne było liczne; po aresztowaniu i na zesłaniu sytuacja, rzecz jasna, diametralnie się zmieniła. W toku całej narracji takim mentalnym punktem odniesienia i identyfikacji jest dla niej raczej szeroko pojęta wspólnota wykształconych Europejczyków, do której należą też reprezentanci kultury europejskiej. Widać to wyraźnie już w pierwszych rozdziałach, gdzie z pewną pogardą opisuje elitę artystyczną sowieckiego Mińska czy spacerujących ulicami zabytkowego, „ekskluzywnego" Leningradu spauperyzowanych Rosjan - przypominających jej swoim wyglądem służbę na wychodnym - a także pełen wyższości sposób, w jaki patrzy na nieumiejące zachować higieny, prostackie i wulgarne współwięźniarki, tzw. kryminalne, czy fakt, że udzielającym jej gościny Rosjankom każe postrzegać siebie jako tajemniczą osobę z wyższych sfer ${ }^{96}$. Również Szejna-Miriam nie portretuje siebie w gronie Żydówek polskich,

${ }^{96}$ Por. Turkow Kaminska, Mink Coats..., s. 168-169: „Po moim powrocie do chaty Natasza z twarzą czerwoną z podekscytowania czekała na zewnątrz, machając czymś w moim kierunku. »To dla pani! Tu jest napisane: 'Dla Ruth Zygmuntowny Kamińskiej-Rosner' pięćset rubli z Ambasady Polskiej!«

[...] Była zachwycona i zafascynowana jedwabną bielizną przesłaną mi przez matkę. Niskim głosem rzekła zakłopotana, iż wie, że chyba nigdy nie robiłam prania własnoręcznie, więc z radością mi pomoże. [...] Następnie dodała: »Proszę się nie obawiać. Dochowam tajemnicy! Ale ja wiem. Zgadłam to od razu, gdy panią ujrzałam. Wiedziałam, że skrywa pani tajemnicę na swój temat. I ten czek, który dostała pani z Ambasady, upewnił mnie, że mam rację«.

Zapytałam, co ma na myśli.

»[...] Jestem nauczycielką i wiem, że polski król nazywał się Zygmunt, więc od razu zgadłam, że pani jest jego córką. Jest pani polską księżniczką na wygnaniu, prawda?« 
bo ich w powojennej Moskwie nie było. Towarzyszkami jej niedoli były natomiast Żydówki sowieckie. O tym, że Broderzonowa wielokrotnie podkreśla w swoich wspomnieniach różnice mentalne między nimi a sobą, już wcześniej wspominałam. Jednym zdaniem - wszystkie autorki łączy wyniesiony z Polski wspólny kapitał kulturowy, stanowiący fundament pewnego rodzaju mentalności (co wyraża się też w takich negatywnych aspektach jak typowo polska rusofobia), natomiast polskość pojmowana jako wspólnota z Polakami już fundamentem ich autoidentyfikacji nie jest.

Na zakończenie warto dodać, że na podstawie analizy jedynie trzech tekstów nie można sformułować zniuansowania wniosków na temat tego, co wnoszą kobiece wspomnienia do żydowskiej autobiograficznej literatury łagrowej. Aby odpowiedzieć na to pytanie, należy nie tylko przejrzeć obszerniejszy korpus wspomnień kobiecych, ale przede wszystkim zdefiniować specyfikę żydowskiej literatury łagrowej jako takiej ${ }^{97}$. Warto jednak podkreślić, że lektura opowieści Oli Watowej, Ruth Turkow-Kamińskiej i Szejny-Miriam Broderzon dowiodła, iż wspomnienia z okresu tułaczki po ZSRR - niezależnie od tego, czy spisane przez kobiety, czy przez mężczyzn - mogą być doskonałym materiałem do badania różnorodności postaw tożsamościowych reprezentowanych przez żydowskich obywateli II Rzeczypospolitej ${ }^{98}$.

\section{Bibliografia}

\section{1. Źródła opublikowane}

Broderzon Szejne-Miriam, Majn lajdns-weg mit Mojsze Broderzon. Di milchome hot gedojert far undz zibecn jor... (Zichrojnes), Buenos Aires 1960.

Turkow Kaminska Ruth, Mink Coats and Barbed Wire, wstęp Harrison E. Salisbury, London 1979.

Watowa Ola, Wszystko co najważniejsze..., Warszawa 2011.

Polska nie była królestwem od setek lat, a ta dziewczyna była nauczycielką! Szukałam słów, ale im dłużej milczałam, tym bardziej ona nabierała pewności, że jej domysł jest słuszny.

Odepchnęła mnie od miski, a ja usiadłam na skraju łóżka, trzymając się za głowę ze zdumienia.

Pani Durach zapytała, co jest nie tak. Pokręciłam głową. Powiedzieć jej o tym - o sowieckiej nauczycielce, która jest wielbicielką rodziny królewskiej - równałoby się ściągnąć zagrożenie dla jej kariery zawodowej, a nawet dla jej wolności”.

${ }^{97}$ Zob. wstępne uwagi na temat specyfiki polsko-żydowskich wspomnień łagrowych w języku polskim: Sucharski, Ocaleni w „domu niewoli”?..., a także w języku jidysz: Ruta, Plejtim 1939-1946... oraz taż, "We were slaves"...

${ }_{98}$ Zob. Ruta, Relacje polsko-żydowskie we wspomnieniach Awroma Zaka... 


\section{Opracowania}

Czermińska Małgorzata, Autobiograficzny trójkąt. Świadectwo, wyznanie i wyzwanie, Kraków 2004.

Czerska Tatiana, Kobiety w tagrach, „Annales Neophilologiarum” (2011), nr 5.

Gawryś Anna, Meandry wspótautorstwa. Przypadek Oli Watowej, [w:] Artyst(k)a: obecność i tożsamość. Manifestacje podmiotowości w gestach i procesach twórczych, red. Magdalena Popiel, Klaudia Węgrzyn, Maciej Kuster, Kraków 2018. Iwasiów Inga, Centralna pteć cywila, [w:] Wojna. Doświadczenie i zapis: nowe źródła, problemy, metody badawcze, red. Sławomir Buryła, Paweł Rodak, Kraków 2006.

Iwasiów Inga, „Niosto ją to, że stała u boku”. O genderowym modelowaniu biografii artystek, „Autobiografia. Literatura. Kultura. Media” (2015), nr 2.

Jelinek Estelle C., Introduction. Women's Autobiography and the Male Tradition, [w:] Women's Autobiography: Essays in Criticism, red. Estelle C. Jelinek, Bloomington 1980.

Lejeune Philippe, Pakt autobiograficzny, tłum. Aleksander Wit Labuda, „Teksty” (1975), nr 5.

Mason Mary G., Inny głos: autobiografie pisarek, [w:]Autobiografia, red. Małgorzata Czermińska, Gdańsk 2009.

Melchior Małgorzata, Społeczna tożsamość jednostki (w świetle wywiadów z Polakami pochodzenia żydowskiego urodzonymi w latach 1944-1955), Warszawa 1990.

Nikliborc Agnieszka, Uwięzione w KL Auschwitz-Birkenau. Traumatyczne doświadczenia kobiet odzwierciedlone w dokumentach osobistych, Kraków 2010.

Prokop-Janiec Eugenia, Żyd - Polak - artysta. O budowaniu tożsamości po Zagładzie, „Teksty Drugie” (2001), nr 1.

Ruta Magdalena, Gułag poetów. Doświadczenie uchodźstwa, łagrów i tułaczki na terenie ZSRR w twórczości polskich pisarzy języka jidysz lat 1939-1949, [w:] Syberiada Żydów polskich. Losy uchodźców z Zagłady, red. Lidia Zessin-Jurek, Katharina Friedla, Warszawa 2020.

Ruta Magdalena, Literatura miejscem negocjowania tożsamości? Obraz relacji polsko-żydowskich w pisarstwie Kalmana Segala na tle literatury jidysz, [w:] Żydowski Polak, polski Żyd. Problem tożsamości w literaturze polsko-żydowskiej, red. Alina Molisak, Zuzanna Kołodziejska, Warszawa 2011.

Ruta Magdalena, Plejtim 1939-1946. Doświadczenie sowieckiego uchodźstwa we wspomnieniach przedstawicieli polskiego Jidyszlandu. Prolegomena, [w:] Jidyszland. Nowe przestrzenie, red. Monika Adamczyk-Garbowska, Joanna Lisek, Magdalena Ruta [przyjęte do druku w 2022].

Ruta Magdalena, Relacje polsko-żydowskie we wspomnieniach Awroma Zaka, jidyszowego twórcy „ocalatego na Wschodzie”. Rozpoznania wstępne, „Stosunki Polsko-Żydowskie. Kultura” 2 (2020).

Ruta Magdalena, "We were slaves": Deportation to a Soviet Forced Labor Camp during WWII as Depicted in the Memoirs of the Polish-Yiddish Writer Avrom Zak, „Jewish Quarterly Review” 111 (2021), nr 1.

Schwarz Jan, Imagining Lives: Autobiographical Fiction of Yiddish Writers, Madison 2005. 
Schwarz Jan, Survivors and Exiles: Yiddish Culture after the Holocaust, Detroit 2015. Sucharski Tadeusz, Kobieta $w$ tagrze stalinowskim $w$ tekstach polskich pisarek, „Konteksty Kultury” 15 (2018), z. 1.

Sucharski Tadeusz, Ocaleni w „domu niewoli”? Żydzi w polskiej literaturze doświadczenia sowieckiego, [w:] Syberiada Żydów polskich. Losy uchodźców z Zagłady, red. Lidia Zessin-Jurek, Katharina Friedla, Warszawa 2020.

Sucharski Tadeusz, Polskie poszukiwania „innej” Rosji. O nurcie rosyjskim w literaturze Drugiej Emigracji, Gdańsk 2008.

\section{Strony internetowe}

Broderzon's almone gekumen kejn Isroel, „Forwerts” (8 stycznia 1957): https://www. nli.org.il/en/newspapers/frw/1957/01/08/01/article/7/?e=-------en-20--1--imgtxIN\%7ctxTI-----------1 [dostęp: 13 lipca 2021].

Sonia (Sheine Miriam) Broderson (Mandelbaum), https://www.geni.com/people/ Sonia-Broderson/6000000010963535561 [dostęp: 13 lipca 2021].

Zieliński Jan, Ola Watowa, „Culture.pl” (październik 2009): https://culture.pl/pl/ tworca/ola-watowa [dostęp: 14 lipca 2021].

Magdalena Ruta

Instytut Judaistyki

Uniwersytet Jagielloński dlamagdaleny@gmail.com 